\title{
HILGARDIA
}

A Journal of Agricultural Science Published by the California Agricultural Experiment Station

\section{REST AND DORMANCY IN GARLIC}

\author{
LOUIS K. MANN \\ and \\ DAVID A. LEWIS
}


Garlic bulbs, both for food and for replanting, are commonly held in storage for many months. If they are planted immediately after harvest, the bulbs do not produce either roots or sprouts, and may be said to be in a state of rest. The rest decreases with time, but the rate of decrease is markedly affected by the temperature at which the bulbs are held. Experiments to determine how length and temperature of storage affect rest in garlic are described in the present paper.

Garlic bulbs were held at a series of temperatures for different lengths of time, and were then planted, again at several temperatures, to determine how quickly they would root or sprout. The results indicate how storage temperature, length of storage, and soil temperature affect the ability of garlic cloves to root and sprout. Production of carbon dioxide by bulbs stored at different temperatures was also determined. These results are compared with similar reports in the literature for other crops, such as potato and onion.

Storage temperature is also known to have a marked effect on the quality of garlic grown from stored bulbs. This aspect of storage is not covered in this paper, and recommendations for storage of bulbs to be used for planting are not made. 


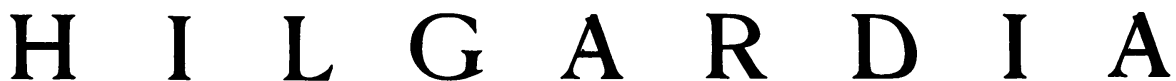

A Journal of Agricultural Science Published by

the California Agricultural Experiment Station

\section{REST AND DORMANCY IN GARLIC}

\author{
LOUIS K. MANN ${ }^{2}$ and DAVID A. LEWIS
}

\section{INTRODUCTION}

GARLIC (Allium sativum L.) is a temperate climate crop reproduced vegetatively by planting the buds or cloves which make up the bulb. As grown commercially in California the cloves are planted in the late fall or winter and usually develop roots and sprouts after the first rains. The young plants grow slowly during the cool season, develop rapidly in the spring, and mature in June or July. The harvested bulbs store well for several months, and those to be used for the next year's planting are usually held in open or uninsulated and unheated buildings until time for planting.

The present paper reports experiments on controlled storage of garlic bulbs during this period between harvest and planting, particularly the effect of storage temperature and length of storage on sprouting and rooting of the cloves. The literature reviewed here covers a limited number of bulb crops in which rest and dormancy have been relatively well studied.

Mann $(1952)^{4}$ reported that garlic bulbs stored at $32^{\circ} \mathrm{F}$ sprouted less readily in storage than bulbs stored at higher temperatures, and also that temperatures at which bulbs were stored before planting affected the growth rate and time of maturity of the plants. To extend these observations, field trials were carried out using controlled bulb storage temperatures and several planting dates. Preliminary observations on these trials (Mann, 1954) indieated that garlic planted immediately after harvest sprouted slowly. Storage at $5^{\circ}$ to $15^{\circ} \mathrm{C}$ for four to six weeks hastened sprouting but storage at $20^{\circ} \mathrm{C}$ did not.

The observations reported here include the sprouting data from these field experiments and the results of laboratory tests in which cloves were sprouted and rooted at controlled temperatures following storage. In addition, two tests on respiration of bulbs in storage are included. The effects of preplanting storage on growth subsequent to sprouting are not presented here.

\footnotetext{
${ }^{1}$ Received for publication February 14, 1956.

${ }^{2}$ Associate Professor of Vegetable Crops and Associate Olericulturist in the Experiment Station, Davis.

${ }^{3}$ Fulbright Fellow, University of California, Davis.

"See "Literature Cited" for citations referred to in text by author and date.
} 


\section{REVIEW OF LITERATURE}

The literature on the onion is discussed in some detail here because of its close taxonomic relation to garlic. For most of the flowering bulbs the production of flowers has been of prime interest (Went, 1948; Hartsema, 1954); although extensive storage studies have been made, there is little information on the rest and dormancy of the vegetative organs.

The terms rest period and dormant period have been defined by Wright and Peacock (1934) and Emilsson (1949) in reference to the potato tuber. To quote Emilsson, "the term 'rest period' will refer to that period immediately following harvest during which the potato tuber will not sprout even under optimal sprouting conditions.... the term 'dormant period' will signify that period during which the tubers may be stored at some temperature suboptimal for sprouting without beginning to sprout or break down physiologically." It should be noted that the dormant period includes and may coinçide with the rest period. We will follow these definitions here except that environmental factors in addition to temperature, e.g., humidity, will be considered as factors controlling the dormant period. While it is necessary to use the term "rest period" in our literature review, rest in stored garlic is lost very gradually, and the term "rest period" has no clear application to garlic. Further comments on this appear in the discussion at the end of the paper.

Since our experiments on garlic deal primarily with duration of storage and storage temperature, references on chemical control of rest and dormancy are not included.

\section{ONION BULBS (Allium cepa)}

Considering the economic importance of the onion crop and the large volume of literature on onions, there is surprisingly little information on the rest and dormancy of the bulbs.

Thompson and Smith (1938) in their many tests on storage of sets do not mention differences in sprouting rate following a wide range of storage temperatures, nor do Heath and Holdsworth in their series of papers on the onion (see Heath and Holdsworth, 1948, for citations). The discovery by Boswell (1924b) that flowering in the onion is mainly a response to storage or field temperatures, directed much of the interest in storage to a study of bolting with little reference to other responses. Finally, the studies to determine the best holding conditions for onions to be used as food have usually employed controlled temperatures with periodic inspections for sprouting, rooting, decay, et cetera. Since both temperature and humidity may affect the growth of sprouts and roots, i.e., control their dormancy after the rest period is over, it is usually not possible to separate dormancy and rest phenomena from such studies.

It has long been recognized that well-matured onion bulbs will fail to sprout or root under conditions ordinarily favorable to growth. Jones (1921), by periodically removing and planting bulbs from storage, demonstrated that the rest disappeared with time, the bulbs sprouting and rooting more quickly the longer they were held. The roots generally appeared before the 
sprouts. He also showed the striking effect of wounding in breaking the rest period of both shoots and roots, work later confirmed by Boswell (1924a) and by Loomis and Evans (1929). More recently Jones et al. (1949) have shown the importance of the rest period to an onion-breeding program. Selections from varieties with short rest periods were harvested in Texas in late March or early April. By the middle of July in Colorado root primordia protruded from the stem plates, and the bulbs were field-planted for vegetative increase. If bulbs were planted and watered before the end of the rest period, there was danger of loss from rot. The bulbs were harvested in late September, completed their rest period by early December, and were ready for greenhouse or field planting for seed production.

Few studies exist on the effect of temperature on the rest period of onions, i.e., controlled storage with periodic plantings under conditions favorable for growth. Following the work of Jones (1921), Boswell (1924a) demonstrated that Yellow Globe Danvers had about an eight-week rest period following harvest if planted in "warm, moist soil." Boswell (1924b) observed that storage for six months at $32^{\circ} \mathrm{F}$ followed by six weeks at $50^{\circ} \mathrm{F}$ caused a much more rapid growth in storage at the latter temperature than at a temperature of $50^{\circ} \mathrm{F}$ for the entire storage period. Field plantings of bulbs stored for eight months at both $32^{\circ}$ and $50^{\circ} \mathrm{F}$ showed greater vigor of growth from the $32^{\circ} \mathrm{F}$ storage. While this is indicative of breaking the rest period, the observed differences were not expressed as rate of sprout emergence. Loomis and Evans (1929) stored onion sets for one to four weeks before planting; they found sprouting most rapid after storage at $102^{\circ} \mathrm{F}$, and decreasingly less rapid at $86^{\circ}$ and $40^{\circ} \mathrm{F}$, and the control which was not stored. They reported "conflicting results in some instances."

Karmarkar and Joshi (1941) stored bulbs of an Indian variety at $32^{\circ} \mathrm{F}$ and at $90^{\circ}$ to $95^{\circ} \mathrm{F}$, and removed them at intervals of one, three, five, and seven months to observe sprouting at $52^{\circ}$ and $68^{\circ} \mathrm{F}$. Apparently the bulbs were not planted but held in storage at these latter temperatures. The rest was broken more rapidly by storage at $32^{\circ} \mathrm{F}$ than at $90^{\circ}$ to $95^{\circ} \mathrm{F}$.

Of the numerous studies on continuous storage at controlled temperatures or controlled temperatures and humidities only a few will be cited here. Boswell (1924b) showed for continuous storage that sprouting was usually greatest at $50^{\circ} \mathrm{F}$, less at $40^{\circ} \mathrm{F}$, and least at $32^{\circ} \mathrm{F}$. Jones (1928) stored bulbs for four months at five temperatures ranging from $3.7^{\circ}$ to $30^{\circ} \mathrm{C}$, and in common storage. Sprouting at the end of storage was progressively greater with increasing temperatures up to $16^{\circ}$ to $20^{\circ} \mathrm{C}$, and then decreased for the $30^{\circ} \mathrm{C}$ storage. This appears to be one of the first reports that high temperatures may reduce sprouting. Thompson (1935) observed less sprouting in storage at $60^{\circ}$ to $70^{\circ} \mathrm{F}$ than at either $40^{\circ}$ or $50^{\circ} \mathrm{F}$, but suggested that this resulted from a lower humidity at the higher temperature. Wright et al. (1935) stored bulbs at $32^{\circ}, 40^{\circ}$, and $50^{\circ} \mathrm{F}$ at controlled humidities. For continuous storage under these conditions it was evident that sprouting increased with increasing temperatures, but was little affected by humidity. Rooting was greatly favored by high humidities but little affected by temperature. Blaauw et al. (1941) stored sets of Zittaur Riesen at eight temperatures between $5^{\circ}$ and $28^{\circ} \mathrm{C}$. They found that sprouting after 28 weeks of storage was greatest at 
$13^{\circ}$ and $17^{\circ} \mathrm{C}$, and less at higher and lower temperatures. After 20 days of additional storage at $9^{\circ} \mathrm{C}$ for all lots, those previously from $13^{\circ}$ to $17^{\circ} \mathrm{C}$ still showed the greatest number of sprouts. In a similar experiment on silverskin onions Hartsema and Luyten (1955) stored sets for about seven months at 10 temperatures from $3^{\circ}$ to $31^{\circ} \mathrm{C}$. Here again the sets stored at $13^{\circ}$ and $17^{\circ} \mathrm{C}$ sprouted most quickly. In both of the above tests some sets were lost prior to the time when sprouts were counted so that the final figures may be somewhat in error.

Magruder et al. (1941), on the basis of two years' storage tests in seven areas in the United States, grouped onion varieties by their suitability for storage. Despite great variability in the production, maturity, time between harvest and storage, and conditions of storage, there was, within varieties, "a remarkable agreement in the storage rating or storage quality." Among varieties, however, there was great variation in storage life, and generally those varieties which rooted and sprouted quickly were the poorest keepers. Bulbs stored at the higher temperatures (mostly below $80^{\circ} \mathrm{F}$ ) lost marketability faster than those stored at lower temperatures.

Karmarkar and Joshi (1941) stored bulbs at nine temperatures from $32^{\circ} \mathrm{F}$ to $90^{\circ}$ to $95^{\circ} \mathrm{F}$. Sprouting occurred most quickly at $48^{\circ}, 52^{\circ}$, and $60^{\circ} \mathrm{F}$, less rapidly at lower temperatures, and least at $75^{\circ}$ to $85^{\circ} \mathrm{F}$ and $90^{\circ}$ to $95^{\circ} \mathrm{F}$. Rooting showed a similar response to storage temperature but occurred more quickly.

Heath and Mathur (1944) give some pertinent data on leaf initiation during storage of sets. They observed that the one- or two-leaf primordia formed at normal temperatures between mid-October and mid-March were initiated mainly during the latter part of that period. The effects of temperatures on leaf initiation were mainly direct, although there was a tendency for sets from treatments preventing leaf initiation to produce initials more rapidly on return to normal temperatures. Leaf initiation at high and low storage temperatures was related to the temperature at which the sets had been grown.

It may be concluded that both the roots and buds of onions are in a state of rest at the time of harvest, and that the rest period varies greatly with variety and disappears with time. Few studies have been made in which freshly harvested bulbs have been stored at a series of temperatures from which samples have been placed at regular intervals into controlled conditions favorable for sprouting and rooting. The works of Jones (1928), Karmarkar and Joshi (1941), Blaauw et al. (1941), and Hartsema and Luyten (1955) suggest that with increasing temperatures above approximately $15^{\circ}$ or $20^{\circ} \mathrm{C}$ the rest disappears more and more slowly. The data of Karmarkar and Joshi (1941) indicate that $32^{\circ} \mathrm{F}$ is more effective in breaking rest than $90^{\circ}$ to $95^{\circ} \mathrm{F}$, but in general we have no information on the effectiveness of low temperatures in breaking rest. The usefulness of temperatures near $0^{\circ} \mathrm{C}$ for commercial storage may depend more on their effect in keeping bulbs dormant than in prolonging their rest period. The effect of temperature on the rest period of roots is even less clear than the effect on sprouts, since humidity may control dormancy (Wright et al., 1935). 


\section{GLADIOLUS CORMS (Gladiolus sp.)}

In the gladiolus, corms may be in a deep rest at the time of harvest. This rest disappears with time, slowly at high temperatures $\left(20^{\circ}\right.$ to $\left.30^{\circ} \mathrm{C}\right)$ or quite rapidly at low temperatures $\left(5^{\circ}\right.$ to $\left.10^{\circ} \mathrm{C}\right)$. After the rest is broken, high temperatures hasten sprouting, early growth, and flowering. This dual effect of temperature has led to considerable confusion in the literature, despite its early recognition by Denny.

Loomis and Evans (1929) reported that sprouting occurred quickly in warm soils, and showed that storage at high temperatures prior to planting led to rapid sprouting. The following storages were considered roughly equivalent values in hastening sprouting: one week at $102^{\circ} \mathrm{F}$; two weeks at $94^{\circ} \mathrm{F}$; three weeks at $86^{\circ} \mathrm{F}$; or four weeks at $77^{\circ} \mathrm{F}$. Denny (1930) suggested that $30^{\circ} \mathrm{C}\left(86^{\circ} \mathrm{F}\right)$ "hastens the rate of growth of buds which can grow" but was effective only after the rest period was broken, and that it would prolong the rest period of freshly harvested corms. Weinard and Decker (1930), Volz and Keyes (1934), Fairburn (1934), and Loomis (1934) all showed that high storage temperatures were more effective in hastening sprouting than were low temperatures. These reports, however, gave too little consideration to the depth of rest of the corms, either as affected by variety or time since harvest. Thus Fairburn states, "high storage temperature aided in breaking the rest period and favored rapid maturity...." and Loomis (1934) accounts for rapid sprouting of California-grown corms in that they "have received the equivalent of a high temperature storage treatment in their curing and handling."

Denny (1936) demonstrated that $3^{\circ}$ and $10^{\circ} \mathrm{C}$ were more effective in breaking rest than $30^{\circ}$ or $35^{\circ} \mathrm{C}$ when applied soon after harvest, but with delayed storage the higher temperatures were relatively more effective in hastening sprouting. Corms stored immediately after harvest at $27^{\circ} \mathrm{C}$ in moist soil may remain in rest for six months to a year or longer, depending on variety (Denny, 1938, 1942). Denny (1939) and Thornton and Denny (1941) also described the rather remarkable respiratory behavior of these long-dormant corms, and Denny (1942) found that their rest may be broken by exposure to as few as five or six hours of low temperature, a treatment which is not effective on fresh corms.

The dual role of temperature in regulating the sprouting of gladiolus corms has been clearly confirmed by Ryan (1955) who showed, in addition, that corms from plants maturing in a warm soil had a deeper rest than those from plants in a cooler soil. Ryan also found that, for breaking the rest period, interrupting storage at $4^{\circ} \mathrm{C}$ with four- to six-day periods at $35^{\circ} \mathrm{C}$ did not influence the rest-breaking effect of the $4^{\circ} \mathrm{C}$ storage.

\section{POTATO TUBERS (Solanum tuberosum)}

There is an enormous volume of literature on rest and dormancy in the potato tuber, but most of it concerns altering the rest or dormant periods by use of chemicals. There are relatively few studies on the influence of temperature. The excellent review of Emilsson (1949) covers all aspects of rest and dormancy in the potato including the influence of temperature. 
The earliest work appears to be that of Müller-Thurgau (1882) which suggested that storage at $0^{\circ} \mathrm{C}$ for 21 days shortened the rest period, but the temperature at which the check sample was held was not given. Later, Müller-Thurgau and Schneider-Orelli (1910) found that if potatoes were held for eight hours in water at $15^{\circ}, 30^{\circ}$, and $35^{\circ} \mathrm{C}$, then planted in soil at $8^{\circ}$ to $10^{\circ} \mathrm{C}$, lots held at $15^{\circ} \mathrm{C}$ sprouted completely in 11 days, those held at $30^{\circ} \mathrm{C}$ sprouted 40 per cent in 11 days, while those held at $35^{\circ} \mathrm{C}$ failed to sprout in that period.

Hopkins (1924) investigated the respiration rate of potatoes at low temperatures. He found, for a three-week period, that the average rate at $32^{\circ} \mathrm{F}$ was about twice that at $30.5^{\circ}$ and $37^{\circ} \mathrm{F}$ and about equal to the rate at $50^{\circ} \mathrm{F}$. In view of Appleman's theory (1914) that shortening of rest was brought about by conditions which accelerated respiration, Hopkins considered that his observed respiratory stimulus at $0^{\circ} \mathrm{C}$ explained breaking of rest by low temperatures.

Rosa (1928) determined the influence of relatively short periods of storage at several temperatures on the average sprouting rate of tubers planted in the greenhouse and in the field. In general, when lots were stored for 19 and 25 days, storage at $30^{\circ} \mathrm{C}$ broke the rest most rapidly, and $0^{\circ} \mathrm{C}$ was more effective than $4^{\circ}, 8^{\circ}$, and $22^{\circ} \mathrm{C}$. Rosa, working with three varieties, found that rest was consistently deeper the more immature the tubers were when harvested. Where tubers were stored continuously at $4^{\circ}, 20^{\circ}$ to $22^{\circ}$, and $27^{\circ}$ to $30^{\circ} \mathrm{C}$, dormancy was broken more effectively the higher the temperature. Wright and Peacock (1934) obtained essentially the same results from tests which were much more extensive, except that their work did not include storage at $0^{\circ} \mathrm{C}$. They also found that immature tubers were in a deeper state of rest than mature tubers when stored at $40^{\circ}, 50^{\circ}, 60^{\circ}$, and $70^{\circ} \mathrm{F}$, and that mature tubers dug early (in the heat of the summer) were in less deep rest than those dug in the fall. In their tests, rest was considered broken when a sample of 10 tubers all sprouted in two weeks at $70^{\circ} \mathrm{F}$ and high humidity, these conditions being considered optimal for sprouting.

Hartman (1934) found that, for tubers previously stored 159 days at $32^{\circ}$, $35^{\circ}, 40^{\circ}$, and $50^{\circ} \mathrm{F}$, the average number of days for emergence in the field was less the higher the storage temperature. This finding agrees with the above work except for emergence after storage at $32^{\circ} \mathrm{F}\left(0^{\circ} \mathrm{C}\right)$. Hartman's material was placed in storage on December 17 and had probably been harvested since mid-October, whereas in Rosa's work, tubers were placed in controlled temperature storage immediately after harvest and stored for only 19 days. Climatic conditions at planting were also different, which emphasizes the value of the laboratory method used by Wright and Peacock in determining termination of rest.

Loomis (1927) stored freshly harvested tubers at $1^{\circ}, 20^{\circ}, 25 \pm 3^{\circ}$, and $30 \pm 5^{\circ} \mathrm{C}$ for 30 days, and then observed their sprouting at $20^{\circ}$ and $25^{\circ} \mathrm{C}$. In general, rest was broken most quickly with increasing storage temperature, but when sprouting was carried out at $20^{\circ} \mathrm{C}, 1^{\circ} \mathrm{C}$ storage appeared to have broken rest at least as quickly and possibly more quickly than $20^{\circ} \mathrm{C}$ storage.

Snell (1932) showed that eight days at $32^{\circ} \mathrm{C}$ reduced rest more than eight days at $1^{\circ} \mathrm{C}$ when tubers were subsequently placed in moist sand at $20^{\circ} \mathrm{C}$. 
With an alternating treatment-eight days at $30^{\circ}$ to $32^{\circ} \mathrm{C}$, eight days at $1^{\circ} \mathrm{C}$, and eight days at $30^{\circ}$ to $32^{\circ} \mathrm{C}$-rapid sprouting ensued. Increasing the length of the alternated periods from one to eight days caused increasing breaking of rest. Respiration of potatoes at $0.22^{\circ} \mathrm{C}$ was greater than at $-0.83^{\circ}$ and $1.17^{\circ} \mathrm{C}$, and about equal to the rate at $9^{\circ} \mathrm{C}$. Newton (1927) also reported that $0^{\circ} \mathrm{C}$ stimulated respiration in potatoes. In addition, rest decreased more rapidly at $5^{\circ}$ than at $20^{\circ} \mathrm{C}$, a difference apparent after as little as two weeks at these temperatures. This observation is not in agreement with general findings, as typified by the results of Wright and Peacock. Tedin (1938) found that only in an early variety did storage at $0^{\circ} \mathrm{C}$ for 6 to 21 days cause more rapid and abundant sprouting than in lots planted when $0^{\circ} \mathrm{C}$ storage began. Sprouting data were taken on both treatments about seven weeks after the experiment was set up.

Perhaps the most extensive tests are those of Hogetop (1930). Rest decreased in tubers stored at $2^{\circ}$ to $4^{\circ} \mathrm{C}$, reaching a minimum after about 6 to 10 months. Beyond this period, rest seemed to increase again and by 16 months tubers failed to sprout when placed under suitable conditions. Hogetop also tested 16 different temperatures from $4.5^{\circ}$ to $33^{\circ} \mathrm{C}$ for efficiency in breaking rest. The most effective was $24^{\circ} \mathrm{C}$, cooler and warmer temperatures being less effective the farther they deviated from this temperature.

The recent work of Emilsson (1949) is in agreement with previous general findings that $20^{\circ} \mathrm{C}$ was more effective than $10^{\circ}$ and $5^{\circ} \mathrm{C}$ in breaking rest. He showed that rest in immature tubers was deeper than in mature tubers when stored at $4.5^{\circ}, 10^{\circ}$, and $20^{\circ} \mathrm{C}$. In addition, he reported that at $20^{\circ} \mathrm{C}$, rest was broken more effectively under high than under low humidity and that at high humidity, $0^{\circ}$ to $20^{\circ} \mathrm{C}$ were about equally effective. Rosa (1928) also found that at $22^{\circ} \mathrm{C}$, rest was broken more rapidly under high humidity than at humidities near 55 per cent. This difference was not apparent for storage at $4^{\circ}$ and $30^{\circ} \mathrm{C}$. Thornton (1939) found that at $23^{\circ}$ to $28^{\circ} \mathrm{C}$, freshly harvested tubers sprouted in 30 days when stored in moist moss and in 50 days in "room" atmosphere.

In summary, it seems to have been generally found that rest and dormancy in potato tubers are broken more rapidly with increasing temperatures from about $5^{\circ}$ to about $30^{\circ} \mathrm{C}$, although Newton's results (1927) are not in accord. Rest would appear to be broken more rapidly at $0^{\circ} \mathrm{C}$ than at intermediate temperatures, although Hartman (1934) did not find this to be so. Rest is broken more rapidly at $20^{\circ}$ to $28^{\circ} \mathrm{C}$ where humidity is high than where humidity is intermediate, but at $4^{\circ}$ and $30^{\circ} \mathrm{C}$, Rosa (1928) found humidity to have no effect on breaking of rest. Respiration of tubers at $0^{\circ} \mathrm{C}$ is more rapid than just below or above that temperature and is about equal to the rate at $10^{\circ} \mathrm{C}$. Rest is deeper in immature tubers than in mature tubers, whereas mature tubers harvested early, in the heat of the summer, are in a less deep state of rest than mature tubers dug in the late fall.

\section{FIELD TESTS ON SPROUT EMERGENCE IN GARLIC MATERIALS AND METHODS}

The clonal lines used were of the Late variety (see Mann and Minges, 1953, for varietal descriptions), derived from single-bulb selections from com- 
mercial fields, and increased at Davis for several years. These lines are designated by arbitrary numbers.

The garlic was stored as unbroken bulbs, usually in paper bags. The controlled temperature rooms were maintained within $\pm 1 / 2^{\circ} \mathrm{C}$ of the temperatures indicated, and humidity was not controlled.

Before planting, the garlic was broken into cloves by hand. Small and unusually large cloves were discarded and the remaining cloves examined carefully to eliminate doubles, i.e., cloves with two storage leaves or shoots within a single protective leaf. Cloves were planted by hand in two rows, 12 to 14 inches apart, on raised beds. Spacing between cloves was usually 2 to 3 inches in the row and the beds were generally 40 inches from center to center. In some tests only alternate beds were planted to facilitate observations during wet weather. The plots were hand-weeded, irrigated if the beds were dry at the time of planting, and irrigated several times during the spring and summer. Culture in general followed the commercial practices in California (Mann and Minges, 1953).

Counts of emerged sprouts were made at weekly intervals. Where more than one line was used in a test the numbers of sprouts from all lines were averaged. Graphs showing total sprouting with time were constructed for each storage temperature and planting date, and from these was read the time until 50 per cent of the cloves had emerged. No corrections were made for cloves which failed to emerge, as emergence in most lots was 100 per cent and the minimum observed for any lot was 90 per cent.

For certain lots where a counting date was missed, or where over 50 per cent of the cloves sprouted during the first week, the days to 50 per cent emergence were estimated graphically. These estimated values are all indicated in the graphs.

\section{Davis Test, 1952-53}

This test was conducted on the University Farm at Davis. Clonal line 7-4 was harvested at Davis on July 29 to 30, 1952, and held in slatted crates in the open on the north side of a large building until 20 days later, on August 19, when the bulbs were placed in storage. Bulbs were placed at $0^{\circ}, 5^{\circ}, 10^{\circ}, 15^{\circ}$, and $20^{\circ} \mathrm{C}$ and a lot of 40 cloves planted in the field from each temperature after $3,6,9,12,17$, and 24 weeks of storage.

\section{El Centro Test, 1953-54}

This test was conducted on the Meloland Research Station near El Centro. Lines 1-4 and 7-1, which had been harvested at Davis on August 10 to 11, 1953 , were used. The bulbs were cured about one week in the field, placed in a well-ventilated bulb house, and then into storage on August 20, nine days after harvest. Bulbs were held at $0^{\circ}, 5^{\circ}, 10^{\circ}, 15^{\circ}$, and $20^{\circ} \mathrm{C}$ and planted from each temperature after about $4,8,12,15$, and 20 weeks of storage. Sixty cloves were planted for each storage temperature and line on each date, except for the four weeks' storage where 80 cloves per line were used.

The bulbs were held in storage rooms at Davis and shipped to the Meloland Station for planting, so that during the period between shipping and planting, which varied from four to seven days, they were at unknown temperatures. The actual planting dates are given in figure 1, and the actual days in 
storage were $25,53,81,105$, and 137 . The weeks of storage indicated in figure 1 are approximate only.

\section{Davis Test, 1953-54}

This test was conducted with clonal lines $1-2,4-10,7-1$, and $7-4$. These lines had the same history as lines $1-4$ and $7-1$ of the El Centro test, and went into the same storage temperatures on the same day. Lots of 60 cloves were planted from each line and each temperature after $4,8,12,16,20$, and 24 weeks of storage.

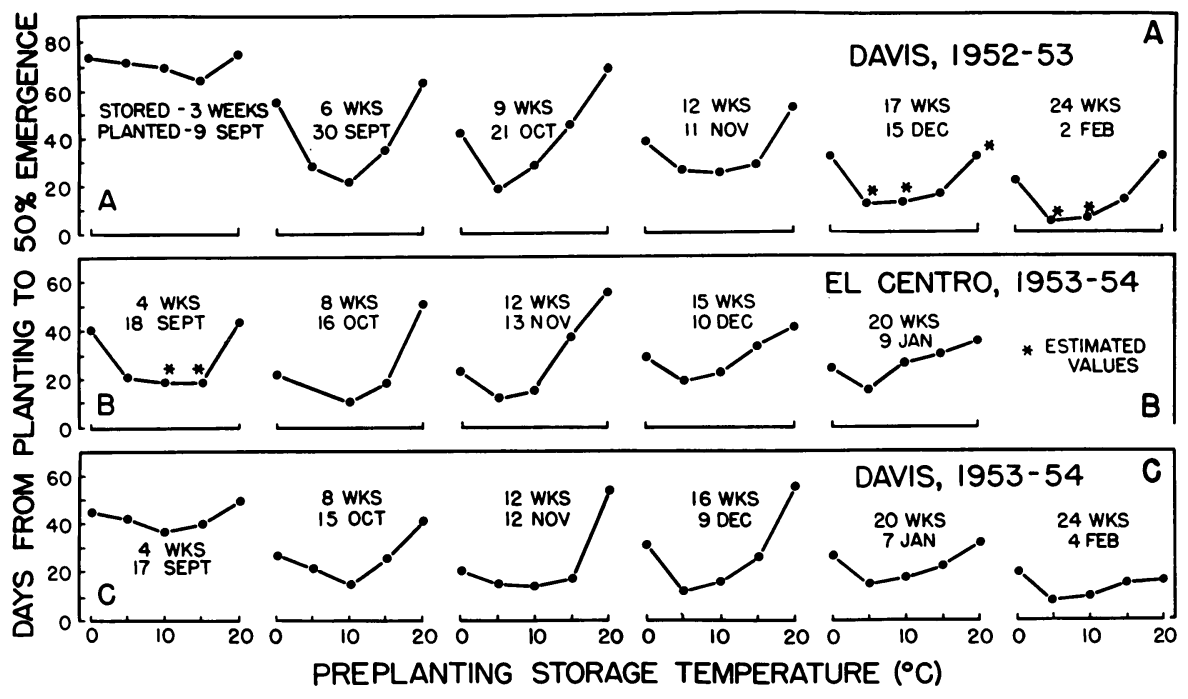

Fig. 1. Field data showing days from planting to 50 per cent sprout emergence of garlic planted after 3 to 24 weeks of storage at $0^{\circ}, 5^{\circ}, 10^{\circ}, 15^{\circ}$, and $20^{\circ} \mathrm{C}$. For the Davis $1952-53$ test, each point is based on 40 cloves; for the El Centro test, 120 cloves; and for the Davis 1953-54 test, 240 cloves.

\section{RESULTS OF FIELD TESTS}

Days from planting to 50 per cent sprout emergence for the three field tests are shown in figure 1 . The most conspicuous response shown in these tests was the effect of bulb storage temperature on time of sprouting. Some of the differences observed in the field were quite striking. For example, for the 1953-54 test at Davis, half of the cloves from bulbs stored at $10^{\circ} \mathrm{C}$ for eight weeks had sprouted 15 days after planting, but no sprouts had yet appeared from the $20^{\circ} \mathrm{C}$ storage lot planted on the same date.

In general, storage at intermediate temperatures favored early sprouting as compared with storage at $0^{\circ}$ or $20^{\circ} \mathrm{C}$. Cloves from bulbs stored at $20^{\circ} \mathrm{C}$ generally sprouted last, with $0^{\circ} \mathrm{C}$ storage next. Of the intermediate temperatures, the most effective storage for early emergence varied with the length of the storage period. Fifteen degrees were perhaps most effective for the shortest storage period, $10^{\circ} \mathrm{C}$ for periods of intermediate length, and finally $5^{\circ} \mathrm{C}$ for periods of three to four months or more.

Garlic is in a state of rest immediately after harvest, and for the three field 
tests the days to 50 per cent emergence decreased markedly between the first and second planting dates (fig. 1). For later planting dates the mean sprouting times did not continue to decrease uniformly. For the $1953-54$ test at
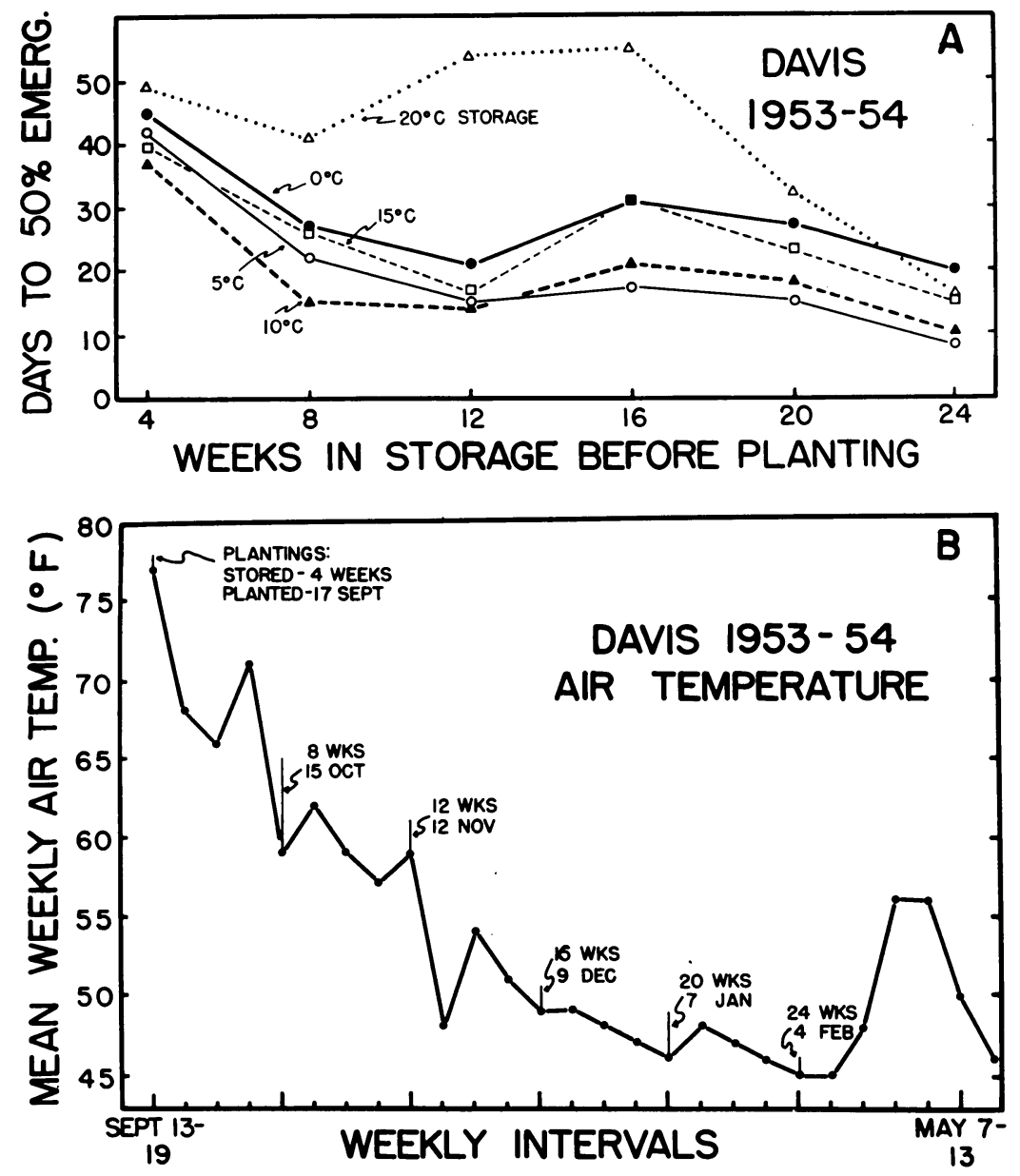

Fig. 2. A, field data showing days from planting to 50 per cent sprout emergence of garlic stored for six periods varying in length from 4 to 24 weeks. Compare with figure 3 , C, which shows the same data expressed on a degree-day basis. B, mean weakly U.S. Weather Bureau air temperatures at Davis for the season during which the data in the upper graph were taken.

Davis these changes in sprouting time with storage are shown in figure $2, \mathrm{~A}$ a replot of the data of figure 1 , C. Figure 2, B, showing the mean weekly air temperatures for the 1953-54 growing season at Davis, suggests that the low temperatures after the plantings of December 9 (16 weeks' storage) and January 7 ( 20 weeks' storage) may have delayed their sprouting.

To adjust for these temperature fluctuations, mean daily temperatures above $40^{\circ} \mathrm{F}$ were summed, and the degree days between planting and 50 
per cent sprouting for each lot plotted against storage time (fig. 3, C). Such an adjustment is approximate since the temperature factor only was considered, air rather than soil temperatures were used, and the $40^{\circ} \mathrm{F}$ base line

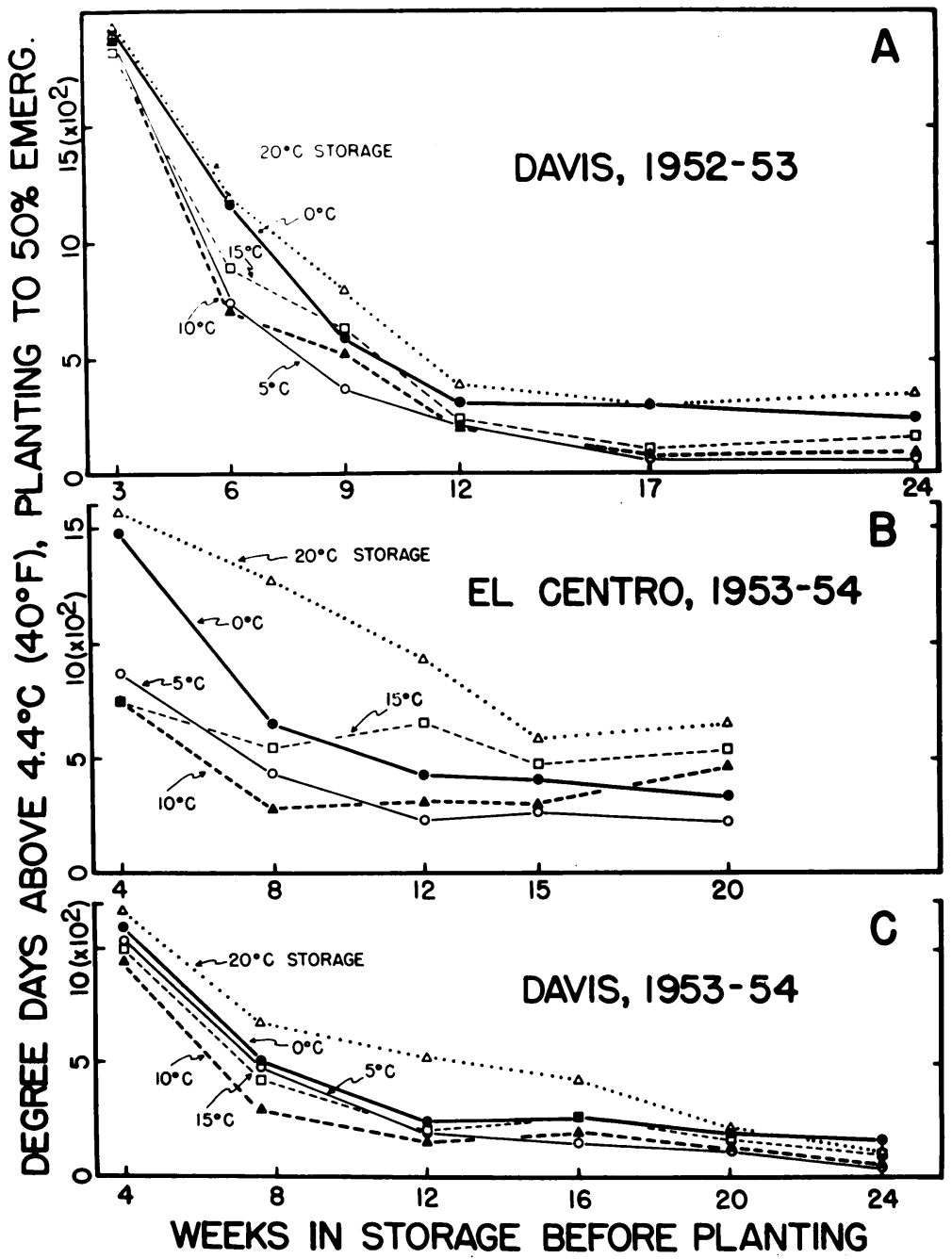

Fig. 3. Field data on sprout emergence of garlic expressed as degree days above $40^{\circ} \mathrm{F}$ from planting to 50 per cent emergence. Compare part $\mathrm{C}$ of this figure with the data presented in figure 2 .

was arbitrarily chosen, but it indicates that clove rest decreases progressively with time at all the temperatures studied.

Figure 3, A and B are similar transformations for the 1952-53 test at Davis and the test at El Centro. The slopes of the curves in figure 3 are dependent on the base chosen for temperature summation, and thus indicate only that rest decreases with time. Because real values cannot be determined for this 
decrease in rest, it is not possible to estimate the effect of soil temperature on rate of sprout emergence, other than to observe that low field temperatures retarded sprouting.

\section{SPROUT EMERGENCE AT CONTROLLED TEMPERATURES}

In the tests described, the cloves were planted in the field over a period of several months, and so sprouted under widely fluctuating soil temperatures. To eliminate this variable, two tests were run in which the cloves, following preplanting storage treatment, were sprouted in flats of moist sand in controlled temperature rooms.

\section{MATERIALS AND METHODS}

\section{First Test}

The garlic used was from clonal line 4-10 grown at Davis and dug July 19, 1954. After harvest the bulbs were dusted with sulfur and later fumigated with 2.5 pounds of methyl bromide per 1,000 cubic feet of space at $80^{\circ} \mathrm{F}$ for two hours. These treatments were applied to control the mite Aceria tulipae Keifer. Between the end of July and September 4, when all lots were placed in storage at controlled temperatures, the bulbs were held in a well-ventilated, unheated storage house. On September 4, five paper bags of 30 to 32 bulbs each were placed in each of the storage rooms at $0^{\circ}, 5^{\circ}, 10^{\circ}, 15^{\circ}$, and $20^{\circ} \mathrm{C}$. On each of five planting dates spaced four weeks apart-October 1 , 29; November 26; December 24, 1954; and January 21, 1955-one bag of bulbs was removed from each room. After breaking the bulbs and discarding small, diseased, and very large cloves, 204 cloves were selected from each bag and separated into four groups of 51 cloves. One group went to each of the sprouting temperatures: $5^{\circ}, 10^{\circ}, 15^{\circ}$, and $20^{\circ} \mathrm{C}$. Thus each of the sprouting temperatures received five lots of 51 cloves, each from a different storage temperature. The cloves were planted in flats of previously watered sterile sand and covered with a uniform layer of wet sand about $7 \mathrm{~mm}$ thick. Three flats were used for each sprouting temperature. Each lot of 51 cloves was divided among the three flats, 17 cloves per flat, so that each flat had five lots of 17 cloves, each lot from a different storage. Within each flat the lots were randomly arranged. At the time of planting the positions of the cloves in the flats were systematically laid out with a peg-board, and as each sprout appeared a small plastic ring was placed over it. These methods were necessary to facilitate counting, as a total of over 5,000 cloves was planted and each lot was repeatedly checked during a period of several weeks or months.

Counts of sprouts were made daily, though for some lots which were slow to emerge less frequent counts were taken. At the time of counting, the flats were examined and water added if they appeared dry.

The temperature of the storage rooms remained relatively constant, usually within $\pm 1 / 2^{\circ} \mathrm{C}$ of that specified. Since the flats were wet, and humidity was not controlled, thermometers were placed in the sand to check temperature. These temperatures were all near room temperature except in the $20^{\circ}$ $\mathrm{C}$ room where the sand temperature was consistently about $3^{\circ} \mathrm{C}$ lower. Thus 
this sprouting temperature will be referred to hereafter as $17^{\circ} \mathrm{C}$. While consistent, this variation was unfortunate because $17^{\circ} \mathrm{C}$ was so close to the next lower sprouting temperature of $15^{\circ} \mathrm{C}$.

Mean days for sprouting were calculated by multiplying the number of new sprouts on any observation date by the number of days since planting, by summing all such products, and by dividing by the total number of cloves emerged. The cloves sprouted well, in most cases 100 per cent. In the 100 lots of 51 cloves, 49 was the minimum number to sprout in any lot. Mean days from planting to emergence calculated in this way should be equivalent to days to 50 per cent emergence if emergence is normally distributed with time. In the field tests where records of emergence were taken weekly, determination of days to 50 per cent emergence from graphs appeared to be the most reliable. For the laboratory tests both methods of calculating emergence were used and the results compared by pairing for each of the 100 values shown in figure 4 . The days to 50 per cent emergence averaged 1.25 days less than mean days for emergence. This small difference was very consistent $(t=8.65)$, and appears to result from the very slow emergence of the last few cloves to sprout in each lot. The mean days for emergence were chosen for the laboratory sprouting since this period could be calculated, thus avoiding estimation from graphs.

\section{Second Test}

In the first test, cloves from bulbs stored at $20^{\circ} \mathrm{C}$ sprouted more quickly after long periods of storage than cloves from bulbs stored at $15^{\circ} \mathrm{C}$. To check this response a second test was run using bulbs stored at a higher series of temperatures than was used in the first test.

The garlic used consisted of several small quantities of clonal line 4-10 which had received different treatments the previous year. To assure uniformity these were distributed equally among the lots of the present storage test. After harvest in 1954 these bulbs were sulfured and held in an unheated, well-ventilated room. Temperatures recorded in this room between November 12 and 26 remained near $16^{\circ} \mathrm{C}$. On December 8, 1954, two bags of 24 bulbs each were placed in each of the following temperatures: $15^{\circ}, 20^{\circ}, 25^{\circ}$, and $30^{\circ} \mathrm{C}$. At the end of 8 and 16 weeks of storage (February 2 and March $30,1955)$ lots of 51 cloves from all storage temperatures were placed to sprout at $10^{\circ}$ and $20^{\circ} \mathrm{C}$. The planting procedures and the method of estimating mean days for emergence were the same as in the previous test.

\section{RESULTS}

\section{First Test}

The mean days to emergence of garlic cloves stored at $0^{\circ}, 5^{\circ}, 10^{\circ}, 15^{\circ}$, and $20^{\circ} \mathrm{C}$ for $4,8,12,16$, and 20 weeks and sprouted at $5^{\circ}, 10^{\circ}, 15^{\circ}$, and $17^{\circ} \mathrm{C}$ are shown in figure 4.

This figure, presenting all the data from the first test, indicates clearly several of the factors influencing the sprouting of cloves. It is evident that certain storage temperatures were much more effective than others in decreasing rest, that there was a general decrease in clove rest with holding in storage, and that for any particular storage temperature and planting date, 
cloves sprouted more quickly the higher the sprouting temperature. These data are in essential agreement with the previous field observations.

Fffect of Preplanting Storage Temperature on Sprouting. The effect of preplanting storage temperatures on rest may be clearly seen in figure 5 , a re-graphing of the sprouting data taken at $5^{\circ}$ and $17^{\circ} \mathrm{C}$. Evidently intermediate temperatures were most effective in breaking the rest of the cloves. Cloves from bulbs stored at $5^{\circ} \mathrm{C}$ before planting sprouted most quickly in nearly all tests, but those from $10^{\circ} \mathrm{C}$ storage were only slightly slower. The response to storage temperatures either higher or lower than $5^{\circ}$ and $10^{\circ} \mathrm{C}$

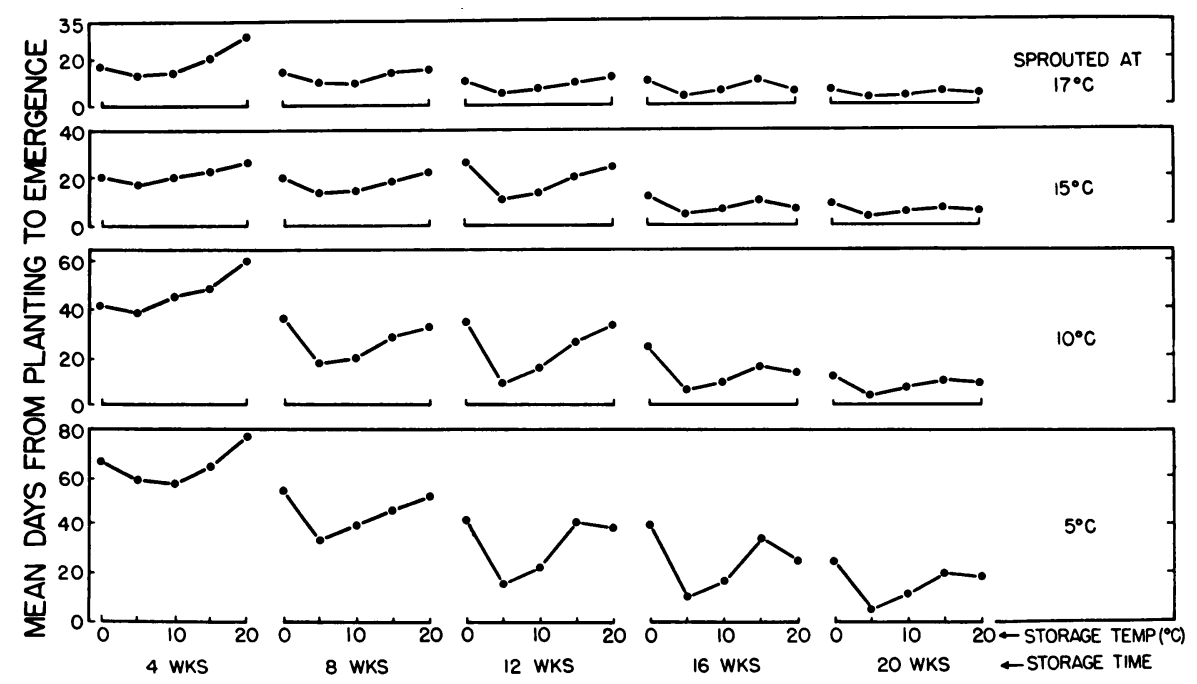

Fig. 4. Mean days from planting to sprout emergence of garlic stored at $0^{\circ}, 5^{\circ}, 10^{\circ}, 15^{\circ}$, and $20^{\circ} \mathrm{C}$ for $4,8,12,16$, and 20 weeks, and then sprouted in flats of sand held at $5^{\circ}, 10^{\circ}$, $15^{\circ}$, and $17^{\circ} \mathrm{C}$. Each point is based on a sample of 51 cloves.

varied with the length of the storage period and also somewhat with the sprouting temperature. At the end of four weeks of storage, cloves from bulbs stored at $20^{\circ} \mathrm{C}$ sprouted most slowly, but with increasing storage time, cloves from bulbs stored at $0^{\circ} \mathrm{C}$ were the slowest. This was true at all sprouting temperatures. It will also be noted that with increasing storage time the $15^{\circ}$ and $20^{\circ} \mathrm{C}$ storage temperatures reversed their relative posititions. With only one exception among all the sprouting temperatures, cloves stored 12 weeks or less sprouted more quickly after $15^{\circ} \mathrm{C}$ than after $20^{\circ} \mathrm{C}$ storage. For longer storage periods-16 and 20 weeks - the $15^{\circ} \mathrm{C}$ storage lots sprouted more slowly than did the $20^{\circ} \mathrm{C}$ lots.

Effect on Sprouting of Length of Storage Before Planting. The longer the bulbs were stored before planting, the more quickly the cloves sprouted. Figure 5 shows this for two sprouting temperatures, $5^{\circ}$ and $17^{\circ} \mathrm{C}$. It will be noted for the lots sprouted at $17^{\circ} \mathrm{C}$ that cloves from bulbs stored at $15^{\circ} \mathrm{C}$ required longer to sprout after 16 than after 12 weeks of storage. In the data of the first test there were six reversals of this type (see fig. 1) out of 80 possible comparisons. 
Decrease in rest with storage varied slightly with the temperatures at which the cloves were sprouted, but was most markedly affected by storage temperature. This is indicated in figure 6 , where the sprouting time after 20 weeks of storage is expressed as a percentage of the sprouting time after four weeks of storage. Each of the bulb storage temperatures is presented as a separate line. The relative positions of the curves are indicative of the effects of storage temperature on rest, but it must be kept in mind that in figure 6 the curves are based on two storage periods only- 4 and 20 weeks. This accounts in part for the low position of the curve representing $20^{\circ} \mathrm{C}$ storage

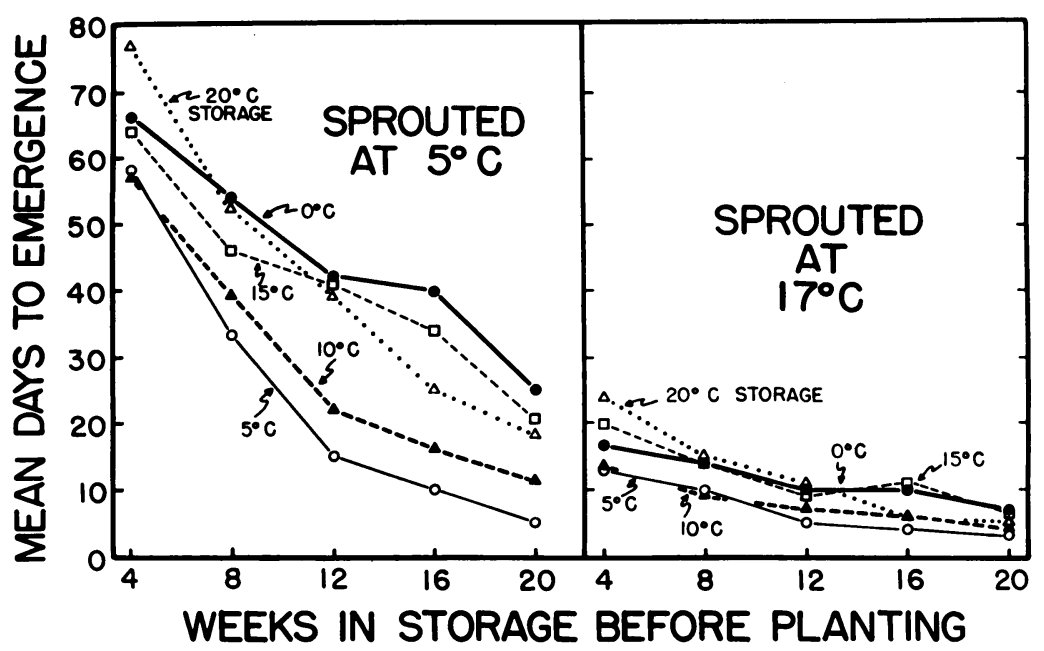

Fig. 5. Mean days from planting to sprout emergence of garlic stored at $0^{\circ}, 5^{\circ}, 10^{\circ}, 15^{\circ}$, and $20^{\circ} \mathrm{C}$ for $4,8,12,16$, and 20 weeks, and sprouted at $5^{\circ} \mathrm{C}$ (left) and $17^{\circ} \mathrm{C}$ (right). Based on data from figure 4.

- the relative time required for sprouting decreased markedly for bulbs in this storage after 16 and 20 weeks.

Cloves from bulbs stored at $0^{\circ} \mathrm{C}$, where changes with storage time were least rapid, required 30 to 40 per cent as long to sprout after 20 weeks as they did after four weeks of storage; at the other extreme, cloves from bulbs stored at $5^{\circ} \mathrm{C}$ for 20 weeks required only 9 to 23 per cent as long to sprout. These differences in emergence time may also be expressed as rates. For the 16 weeks between the first and the last planting dates the decrease in mean sprouting time varied from a minimum of 0.62 day (for cloves stored at $0^{\circ}$ $\mathrm{C}$ and sprouted at $17^{\circ} \mathrm{C}$ ) to a maximum of 3.3 days (for cloves stored at $5^{\circ} \mathrm{C}$ and sprouted at $5^{\circ} \mathrm{C}$ ) per week of storage. While this variation was associated mostly with storage temperature, the temperature at which the cloves were sprouted had a quite consistent effect. Figure 6 shows that the ratio of emergence time after 20 weeks of storage to emergence time after four weeks of storage, expressed as a percentage, was generally least when cloves were sprouted at $10^{\circ} \mathrm{C}$. This means that at $10^{\circ} \mathrm{C}$ the difference in level of rest of cloves from bulbs stored for 4 and 20 weeks was relatively 
greater than for other sprouting temperatures. No obvious explanation appears for this behavior at $10^{\circ} \mathrm{C}$.

Effect of Sprouting Temperature on Sprout Emergence. While it was evident from figure 4 that cloves sprouted more quickly at higher than at lower temperatures, this can be shown more clearly by plotting sprouting temperature against mean days for emergence. These data for the 4- and 20 -week storage periods are shown in figure 7 .

The effect of temperature on rate of sprouting may also be illustrated by the ratio between days to mean emergence at two temperatures. Such a com-

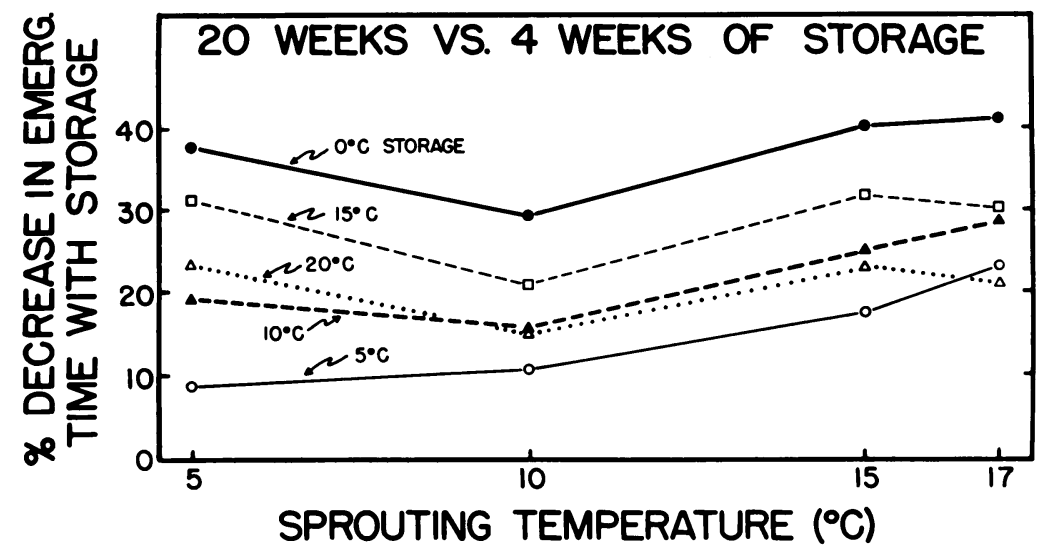

Fig. 6. Mean days to sprout emergence after 20 weeks of storage expressed as a percentage of the mean days to emergence after four weeks of storage. Data are presented for five preplanting storage temperatures and four sprouting temperatures. Data derived from figure 4 .

parison between $5^{\circ}$ and $15^{\circ} \mathrm{C}$ is shown in figure 8 . Since the temperatures compared in figure 8 are 10 degrees apart, the figures graphed correspond to temperature coefficient $\left(Q_{10}\right)$ values. Similar values computed for $5^{\circ}$ and $10^{\circ} \mathrm{C}$ and for $10^{\circ}$ and $15^{\circ} \mathrm{C}$ vary considerably from those shown in figure 8 , and the available data do not appear adequate to construct a reliable $Q_{10}$ curve over the temperature range used for sprouting, i.e., $5^{\circ}$ to $17^{\circ} \mathrm{C}$. The curve shown does suggest that sprouting is two or three times as rapid at $15^{\circ}$ as at $5^{\circ} \mathrm{C}$. The data are inadequate to assess the effect of the storage temperature before planting.

Total Time from Beginning of Storage to the Day of Mean Emergence. Figure 4 shows, for any period of preplanting storage, that earliest emergence followed storage at $5^{\circ} \mathrm{C}$ and sprouting at $17^{\circ} \mathrm{C}$. It is interesting to compare, for these data, the total time from the beginning of storage to the day of mean emergence, i.e., the combinations of storage and sprouting by which cloves can be made to sprout most quickly.

For any one storage and sprouting temperature, the total time between placing in storage and the day on which mean emergence occurred was greater, the longer the storage period. However, this was not always true for comparisons between different storage temperatures. For example, for sprouting at $5^{\circ} \mathrm{C}$, the total number of days between storing and mean emer- 
gence after eight weeks at $5^{\circ} \mathrm{C}$ storage was 15 days less than after four weeks at $20^{\circ} \mathrm{C}$ storage. Even after 12 weeks at $5^{\circ} \mathrm{C}$ storage the total number of days between storing and mean emergence was five days less than after four weeks

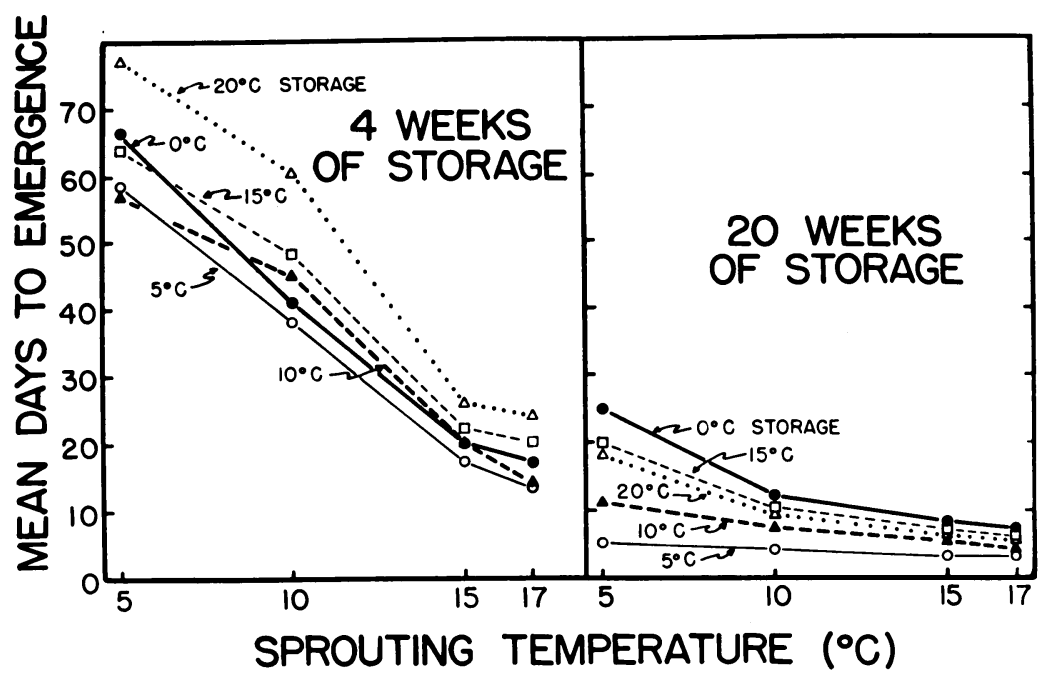

Fig. 7. Mean days to sprout emergence for garlic stored at five temperatures for 4 and 20 weeks and sprouted at four temperatures. Data based on figure 4.

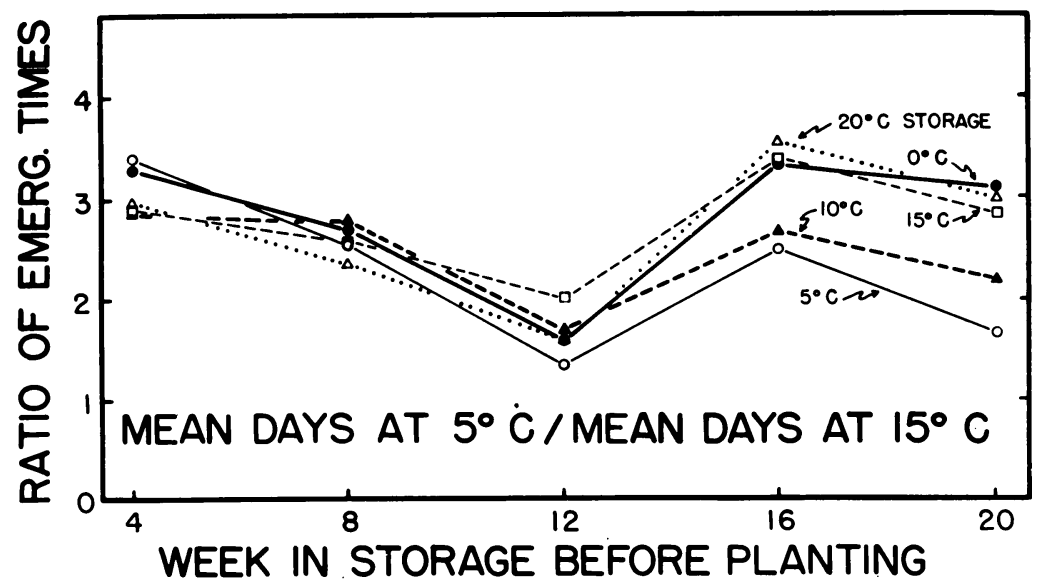

Fig. 8. Ratio-mean days to sprout emergence at $5^{\circ} \mathrm{C} /$ mean days to emergence at $15^{\circ} \mathrm{C}$. Data for five preplanting storage temperatures and five storage periods. Data based on figure 4.

at $20^{\circ} \mathrm{C}$, and 11 days less than after eight weeks at $0^{\circ} \mathrm{C}$. These differences result from differences in rate of decrease of rest at the several storage temperatures.

Another interesting comparison can be made between samples which were stored and sprouted at the same temperature. These samples allow an esti- 
mation of the effect of temperature on rest, since there was no shift in temperature between the storage and sprouting conditions.

For storage and sprouting at $5^{\circ} \mathrm{C}$, eight weeks of storage increased the total storing to emergence time by only three days over storage for four weeks. That is, 28 days of additional storage at $5^{\circ} \mathrm{C}$ reduced the mean number of days to emergence at $5^{\circ} \mathrm{C}$ by 25 days. Similarly, for storage and sprouting at $10^{\circ} \mathrm{C}$, the second four weeks of storage reduced the mean number of days for emergence by 26 days. Clearly the optimum temperature for reducing rest could have reduced the mean days to emergence by no more

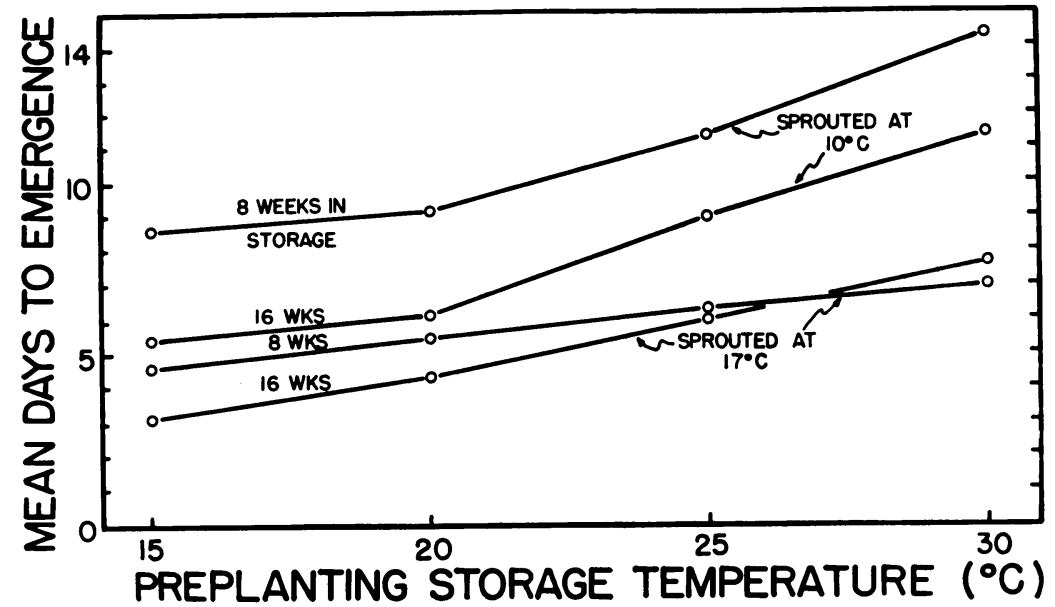

Fig. 9. Mean days from planting to sprout emergence following 8 and 16 weeks of storage at $15^{\circ}, 20^{\circ}, 25^{\circ}$, and $30^{\circ} \mathrm{C}$. Each point is based on a sample of 51 cloves.

than 28 days. Thus $5^{\circ}$ and $10^{\circ} \mathrm{C}$ must be very close to the optimum for reducing rest in garlic.

The only other temperature for which such a comparison can be made is $15^{\circ} \mathrm{C}$. The second four weeks of storage at $15^{\circ} \mathrm{C}$ reduced the mean days to emergence by four days. Sprout emergence at $15^{\circ} \mathrm{C}$ is rapid, requiring only 22 days after four weeks of storage, so that a reduction as great as that observed at $5^{\circ}$ or $10^{\circ} \mathrm{C}$ is not possible here, but the reduction of only four days is indicative of the slow dissipation of rest at $15^{\circ} \mathrm{C}$.

\section{Second Test}

This second test was run to determine if prolonged storage at temperatures of $20^{\circ} \mathrm{C}$ or higher would break rest more rapidly than storage at $15^{\circ} \mathrm{C}$, as was indicated in the first test on emergence at controlled temperatures. Figure 9, giving the mean days to emergence for the lots of the second test, shows that temperatures above $15^{\circ} \mathrm{C}$ did not break rest more rapidly than $15^{\circ} \mathrm{C}$, but that rest was progressively deeper after storages up to at least $30^{\circ} \mathrm{C}$. Field test observations on storages at $15^{\circ}$ and $20^{\circ} \mathrm{C}$ are in agreement with this.

In comparing the first and second laboratory sprouting tests, it should be noted that bulbs for the second test were placed in storage on December 8 , 
a little less than 14 weeks after the storage in the first test had begun. In this interval the bulbs for the second test had been in unheated storage which, for the period of November 12 to 26 remained near $16^{\circ} \mathrm{C}$. By December 8 these bulbs must already have lost much of their initial rest, and the relatively rapid sprouting for all lots of this second test indicated this to be true.

Additional tests, using the higher storage temperatures and freshly harvested bulbs, must be run to clarify the differences in sprouting following high temperature storage reported here.

\section{ROOT EMERGENCE AT CONTROLLED TEMPERATURES}

\section{MATERIALS AND METHODS}

In the sprouting tests described, certain cloves which were very slow to emerge were dug and examined for decay. Among these were cloves which appeared perfectly sound, but which lacked roots as well as sprouts. When replanted these eventually rooted and sprouted. This suggested that both roots and sprouts may be in a condition of rest, and the following tests were devised to determine the effect of preplanting storage temperatures on root emergence.

Cloves used in these tests were large ones discarded from the sprouting tests. Three plantings were made for observing rooting, begun after $81 / 2,12$, and 20 weeks of preplanting storage at $0^{\circ}, 5^{\circ}, 10^{\circ}, 15^{\circ}$, and $20^{\circ} \mathrm{C}$. From the lots at each temperature 50 large cloves were selected and divided into two matched samples of 25 cloves for rooting at $5^{\circ}$ and $15^{\circ} \mathrm{C}$. For the $5^{\circ} \mathrm{C}$ preplanting storage of 12 weeks, samples of 20 cloves were used, and after 20 weeks of preplanting storage the cloves were rooted at $5^{\circ} \mathrm{C}$ only.

Each lot of 25 or 20 cloves was arranged in two rows along the center of a double thickness of cheesecloth $9 \times 30$ inches, the sides were folded in, and the whole rolled up from one end. This was then dipped in water and placed in a loosely covered cardboard carton in the appropriate storage room, $5^{\circ}$ or $15^{\circ} \mathrm{C}$. The roll was periodically moistened with water held in the storage room.

Daily counts were taken on the number of cloves on which at least one root had elongated to $5 \mathrm{~mm}$ or more. When all cloves in each group of five samples had developed $5 \mathrm{~mm}$ roots, the roots were trimmed off and weighed.

For each sample, the counts described above were graphed against days from "planting" and from this graph was read the number of days until 50 per cent of the cloves had roots $5 \mathrm{~mm}$ long.

Counts were also made when the roots were first visible. Results based on first emergence differed in no essential way from those based on $5 \mathrm{~mm}$ of emergence, so only the latter data will be presented. Since cloves of larger than average size were used in these tests, four lots from the same bulbs but of smaller than average size were checked for root emergence (stored 12 weeks at $5^{\circ}$ and $15^{\circ} \mathrm{C}$ and rooted at $5^{\circ}$ and $15^{\circ} \mathrm{C}$ ). Weight data were not taken but root emergence was essentially the same as that presented for the larger cloves. 


\section{RESULTS}

Effect of Preplanting Storage Temperature on Root Emergence and Weight of Roots Produced. The influence of preplanting storage temperatures on rooting is shown in figure 10, in which the period of days to 50 per cent rooting is shown in graph against preplanting storage temperatures for three lengths of storage periods and two rooting temperatures. For rooting at both $5^{\circ}$ and $15^{\circ} \mathrm{C}$, and for all preplanting storage periods $(81 / 2,12$, and 20 weeks), the preplanting storage temperatures may be arranged in decreasing order of rest-breaking ability as follows: $5^{\circ}, 10^{\circ}, 15^{\circ}, 20^{\circ}$, and $0^{\circ} \mathrm{C}$.

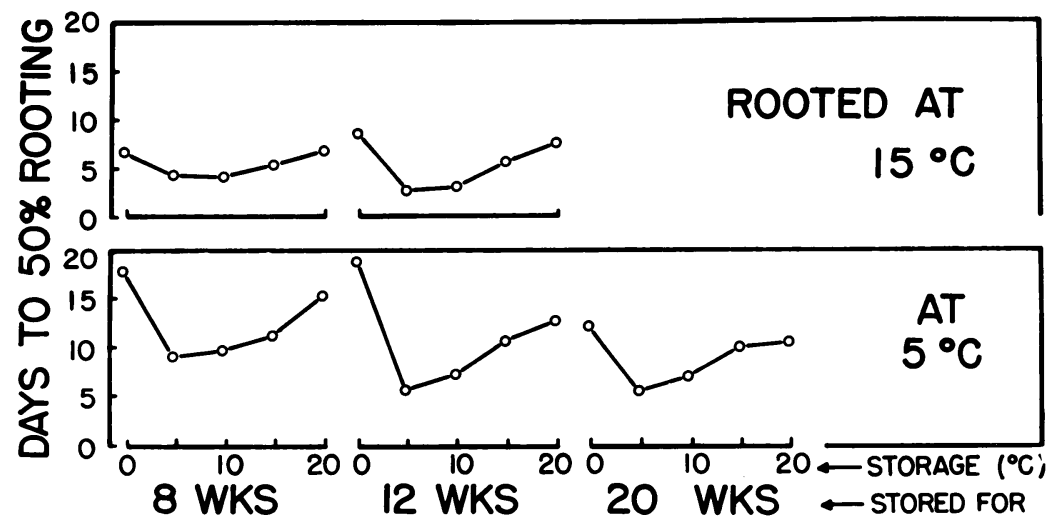

Fig. 10. Mean days from planting to 50 per cent root emergence after storage at five temperatures for 8,12 , and 20 weeks. The samples, consisting of 20 to 25 cloves, were rooted at $5^{\circ}$ and $15^{\circ} \mathrm{C}$.

In the upper left graph, figure $10,5^{\circ}$ and $10^{\circ} \mathrm{C}$ were equally effective as also were $0^{\circ}$ and $20^{\circ} \mathrm{C}$.

In no case did $15^{\circ}$ and $20^{\circ} \mathrm{C}$ reverse their positions in order of effectiveness in breaking the rest of roots, whereas this was noted in the first test on sprouting after long periods of preplanting storage.

For each planting date, and for each rooting temperature, the five samples of cloves were held until all cloves had roots $5 \mathrm{~mm}$ long. Figure 11 shows the cloves for one such series (top line, table 1). At this time the roots were trimmed and weighed. Where clove numbers were less than 25 , weight corrections to a 25 clove basis were made. Results are presented in table 1.

TABLE 1

FRESH WEIGHTS OF ROOTS OF GARLIC CLOVES FOLLOWING SEVERAL STORAGE TREATMENTS AND ROOTED AT TWO TEMPERATURES

\begin{tabular}{c|c|c|c|c|c|c|c}
\hline \hline $\begin{array}{c}\text { Rooting } \\
\text { tempera- } \\
\text { ture }\end{array}$ & $\begin{array}{c}\text { Period in } \\
\text { preplanting } \\
\text { storage }\end{array}$ & $\begin{array}{c}\text { Period under } \\
\text { rooting } \\
\text { conditions }\end{array}$ & \multicolumn{3}{|c|}{$\begin{array}{c}\text { Weights of roots (gm) of 25 cloves and preplanting } \\
\text { storage temperatures }\end{array}$} \\
\cline { 1 - 7 } centigrade & weeks & days & $0^{\circ} \mathrm{C}$ & $5^{\circ} \mathrm{C}$ & $10^{\circ} \mathrm{C}$ & $15^{\circ} \mathrm{C}$ & $20^{\circ} \mathrm{C}$ \\
$5^{\circ}$ & $81 / 2$ & 32 & 3.22 & 8.89 & 13.62 & 10.46 & 3.45 \\
$5^{\circ}$ & 12 & 30 & 2.38 & 12.12 & 13.51 & 7.68 & 3.68 \\
$5^{\circ}$ & 20 & 26 & 4.09 & 9.93 & 10.19 & 6.11 & 5.34 \\
$15^{\circ}$ & 12 & 32 & 7.96 & 13.08 & 17.06 & 9.72 & 5.70 \\
\hline
\end{tabular}


Since each group of five samples representing the preplanting storage temperatures was held until all roots had reached the $5 \mathrm{~mm}$ stage, the roots of early emerging samples elongated for a longer period than those of the late emerging samples. In every test the greatest weight of roots was produced by cloves previously held at $10^{\circ} \mathrm{C}$, in sharp contrast to the results for numbers of days for 50 per cent root emergence $(5 \mathrm{~mm})$ in which a $5^{\circ} \mathrm{C}$ preplanting storage had the most stimulating effect (see fig. 10).

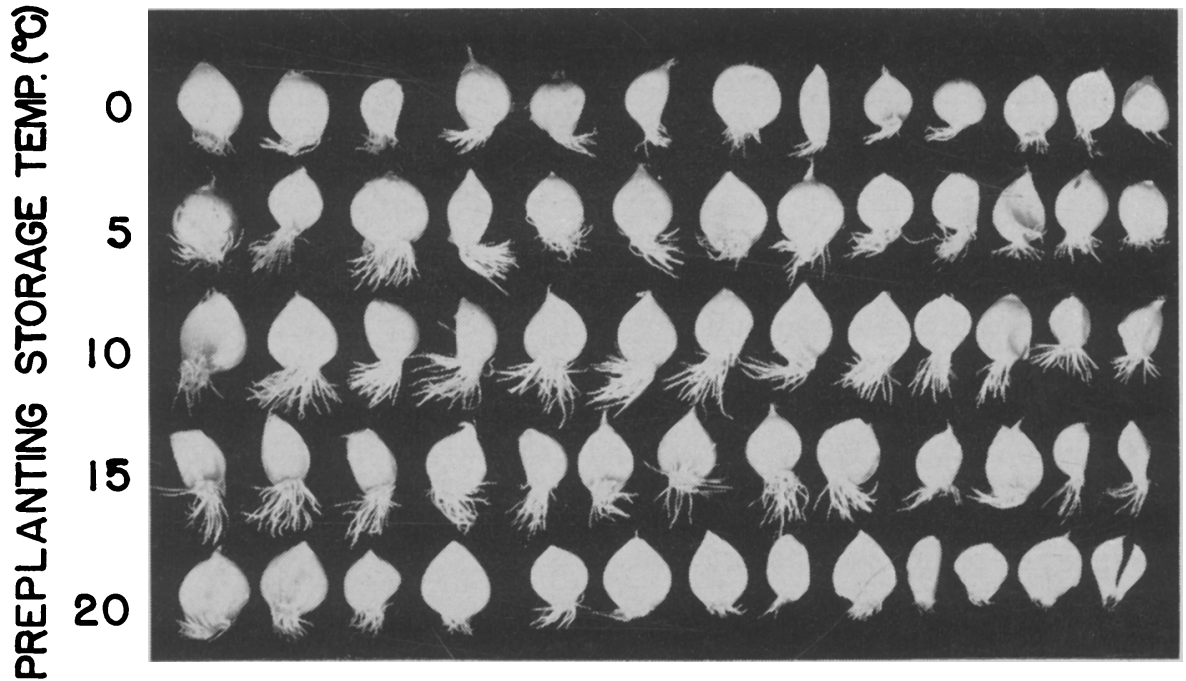

Fig. 11. Samples of cloves photographed at the conclusion of a rooting test-all cloves with at least one root $5 \mathrm{~mm}$ long-and before the roots were trimmed and weighed. This lot had been held in storage at $0^{\circ}, 5^{\circ}, 10^{\circ}, 15^{\circ}$, and $20^{\circ} \mathrm{C}$ for $81 / 2$ weeks before being rooted at $5^{\circ} \mathrm{C}$ for 32 days. Root weights of these samples are shown in the top line of table 1.

Effect on Root Emergence of Length of Storage Before Planting. From the limited data available, rest of roots, like that of sprouts described above, appears to decrease with time in storage.

Effect of Rooting Temperature on Root Emergence. Since rooting tests were carried out at $5^{\circ}$ and $15^{\circ} \mathrm{C}$, a temperature coefficient $\left(Q_{10}\right)$ value for root emergence and elongation is given by a direct comparison of the number of days to 50 per cent rooting at these temperatures for each storage temperature.

These $Q_{10}$ values ranged from 1.7 to 2.7 , averaging about 2.2 , and showed no particular pattern. Thus the rate of root growth at $15^{\circ} \mathrm{C}$ is apparently somewhat over twice that at $5^{\circ} \mathrm{C}$, and essentially the same responses to preplanting storage temperatures are observed at either rooting temperature.

\section{CARBON DIOXIDE PRODUCTION BY GARLIC BULBS MATERIALS AND METHODS}

Production of carbon dioxide (respiration) by mature dry garlic bulbs was determined at a range of temperatures from $0^{\circ}$ to $20^{\circ} \mathrm{C}$ during the storage seasons of 1952-53 and 1953-54. In both years, production of carbon dioxide was measured by the method of Claypool and Keefer (1942). 


\section{Test of 1952-53}

Carefully selected bulbs of line 1-4 were used. These had been harvested July 29 to 30, 1952, and stored in the shade until August 22, 1952, a total of 23 days. On this latter date, six samples, each of 57 bulbs and weighing between 2.3 and $2.4 \mathrm{Kg}$, were placed in respiration containers in controlled temperature rooms at $0^{\circ}, 5^{\circ}, 10^{\circ}, 15^{\circ}, 20^{\circ}$, and $25^{\circ} \mathrm{C}$. The air flowing over the samples was humidified but on September 30,1952, it was changed to nonhumidified air. Respiration readings were taken daily at first and less frequently as storage progressed. In the first two months, about 30 readings were taken on each sample. Storage proceeded for over seven months.

\section{Test of 1953-54}

Carefully selected bulbs of lines 1-4, 7-7, and 6-5, equally distributed among all samples, were used. These had been harvested August 10 to 11, 1953, and stored in a well-ventilated building until November 24, 1953, a period of 105 days. Eleven samples, each of 26 bulbs and weighing about $1.3 \mathrm{Kg}$, were placed in respiration containers with humidified air flow on November 25, 1953 , at $0^{\circ}, 21 / 2^{\circ}, 5^{\circ}, 71 / 2^{\circ}, 10^{\circ}, 15^{\circ}, 20^{\circ}, 25^{\circ}, 30^{\circ}, 35^{\circ}$, and $40^{\circ}$ C. Respiration readings were made daily at first, then at less frequent intervals. In 47 days about 15 readings were taken on each lot. No further readings were taken when mold began to grow on bulbs.

\section{RESULTS}

Rates of respiration at $0^{\circ}, 5^{\circ}, 10^{\circ}, 15^{\circ}$, and $20^{\circ} \mathrm{C}$ for both tests are shown in figure 12. Rates at $25^{\circ} \mathrm{C}$ in $1952-53$, and at $21 / 2^{\circ}, 712^{\circ}$, and $25^{\circ}$ to $40^{\circ} \mathrm{C}$ in 1953-54 are omitted from the results since they were not used in both years $\left(25^{\circ} \mathrm{C}\right.$ excepted) and make the figure overcomplicated.

In the 1952-53 test, during the first 60 days of storage, respiration increased very rapidly at $10^{\circ}$, rapidly at $15^{\circ}$ and $5^{\circ} \mathrm{C}$, while at $20^{\circ}$ and $0^{\circ} \mathrm{C}$ there was but slight increase in respiration rate. At $10^{\circ}, 15^{\circ}$, and $5^{\circ} \mathrm{C}$, the rates of respiration appeared to reach maxima and these levels were then maintained, but the maximum was reached first at $10^{\circ}$ and last at $5^{\circ} \mathrm{C}$. The maximum ultimately reached at $5^{\circ} \mathrm{C}$ was probably higher than that reached at $10^{\circ}$ and $15^{\circ} \mathrm{C}$.

In the 1953-54 test, respiration rates at $15^{\circ}$ and $20^{\circ} \mathrm{C}$ decreased at first, at $0^{\circ}$ and $10^{\circ} \mathrm{C}$ they did not change markedly, and at $5^{\circ} \mathrm{C}$ the rate increased. After about 5 days at $20^{\circ} \mathrm{C}$ and 10 days at $5^{\circ}$ and $15^{\circ} \mathrm{C}$, rates became fairly steady.

The two tests differ in two important respects. In 1952-53, bulbs had been harvested only 23 days before the beginning of the test and during the period the conditions of storage, even in the shade, were warm. The bulbs were probably still in a deep state of rest. In 1953-54, the bulbs had been harvested 105 days and storage conditions had become fairly cool toward the end (November 24, 1953). Thus they would have been in a less deep state of rest. 
The second difference was that bulbs in the first test were warm when moved into controlled storage conditions for respiration measurements. In the second test bulbs had been cold before being moved into controlled conditions. Rapid early evolution of carbon dioxide observed in the second test at $15^{\circ}$ and $20^{\circ} \mathrm{C}$ may have been due to its release from solution within the bulbs and slow diffusion out on transfer from cold to warm conditions. Respiration reached steady rates which were higher, the higher the storage temperatures.

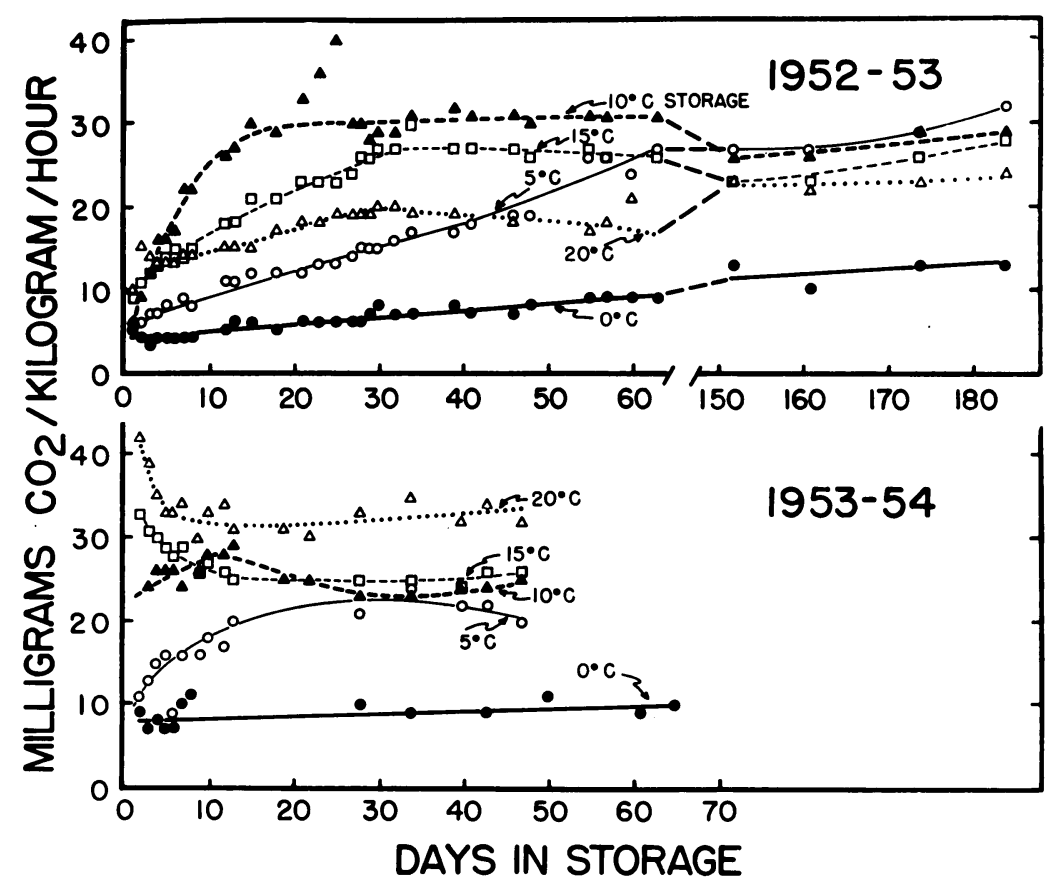

Fig. 12. Carbon dioxide production by stored garlic bulbs. In 1952-53 the test was begun shortly after harvest when the bulbs were in a relatively deep state of rest; in 1953-54 the rest had largely disappeared before the test was started.

In the first test the respiration rates reached after about two months were not proportional to storage temperatures. Rates at $5^{\circ}, 10^{\circ}$, and $15^{\circ} \mathrm{C}$ were high, $20^{\circ} \mathrm{C}$ was intermediate, and $0^{\circ} \mathrm{C}$ was low. With very prolonged storage, respiration at $20^{\circ} \mathrm{C}$ increased. Interpretation of the results at this stage may require consideration of senescence effects which are not well understood.

The data from the first test, in which the garlic was undoubtedly in a fairly deep state of rest, suggest strongly that rate of carbon dioxide production is associated with the rest-breaking process over the range of temperatures studied. Our information on rest breaking during the first month 
of storage is too meager, however, to suggest whether these changes in carbon dioxide output precede, accompany, or follow the rest changes. A more thorough study of rest and respiration during the first month or two of storage would be of considerable interest. No relation was apparent between the level of respiration and relative rest-breaking efficiencies of storage temperatures in the second test, for which bulbs were initially at a low level of rest. This supports an association between carbon dioxide production and rest breaking, as proposed above.

\section{DISCUSSION}

The review of literature on rest and dormancy in onions, gladiolus, and potatoes indicates that, for all of these crops, curves relating storage temperature to rest do not rise or fall uniformly with temperature. For onions, temperatures near $15^{\circ} \mathrm{C}$ may be most effective in decreasing rest, although, particularly for temperatures lower than this, no adequate data are available. Temperatures between $3^{\circ}$ and $10^{\circ} \mathrm{C}$ seem most effective in dissipating rest of gladiolus corms and near $0^{\circ}$ or above $5^{\circ} \mathrm{C}$ for the potato tuber. These figures are only approximate and have been shown to vary with variety, past history, and environmental factors other than temperature. Rest in garlic is lost most rapidly near $5^{\circ}$ or $10^{\circ} \mathrm{C}$ and so resembles the above crops in showing a marked minimum or maximum response to intermediate temperatures.

Since it was pointed out that the "rest period" terminology of Wright and Peacock (1934) is not satisfactory in all respects for the work presented here, the following comments are offered. Rest of vegetative storage organs appears to change gradually, at least when these organs are in storage, and for this reason it is undesirable to say that rest is "broken" at a specific time. For the same reason, the term "rest period" may be objectionable for those storage studies where no sudden change in the level of rest has been demonstrated. An arbitrary standard may be set up, e.g., rest may be considered broken if a sample sprouts or roots within a specified time under standardized conditions (method of Wright and Peacock). This may enable one to determine the length of rest period, but the arbitrary nature of such a period should be kept in mind. Mean days to emergence or days to 50 per cent sprouting or rooting, as used here for garlic, appear to have the advantage of indicating the gradual disappearance of rest by measuring its level; there is no indication of a definite "break" or "period" of rest in stored garlic.

In both rooting and sprouting tests, we have measured the level of rest by the time taken for roots or shoots to elongate a specified amount: for roots, $5 \mathrm{~mm}$ beyond the base of the storage leaf; for sprouts, through the storage leaf and a small depth of soil or sand. Thus, rest is considered ended when sprouts or roots have grown a certain distance.

It should be noted, however, that from the day of planting, the amount of shoot or root elongation required to reach 50 per cent emergence may vary with the preplanting storage treatment. For example, in the test shown in figure 4, many of the cloves stored at $5^{\circ} \mathrm{C}$ for 20 weeks had visible shoots when planted. Cloves stored for the same length of time at $20^{\circ} \mathrm{C}$ had no visible shoots. For this reason, sprouts of cloves stored for long periods at 
temperatures which are effective in decreasing rest may have to undergo little additional elongation to reach mean emergence.

The effect of temperature of storage on sprout and root growth (elongation) may be quite separate from its effect on initiating growth of roots and shoots. For roots, for example, our results suggest that the influence of preplanting storage temperature on emergence is not the same as on growth after emergence. Thus, emergence was most rapid after $5^{\circ} \mathrm{C}$ storage, but the weight of roots produced per sample was greatest after $10^{\circ} \mathrm{C}$ storage. Whether this is also true for shoot growth is not known. Roots emerge and develop considerably in advance of shoots, and the bulk of roots produced by a clove may well influence shoot emergence.

Even if root development does not affect shoot emergence rate, and if a similar differential effect of temperature on shoot emergence and elongation exists as for roots, the greater the distance that the shoot needs to grow before being seen, the earlier will be the apparent "emergence" after the storage temperature for which shoot elongation is most rapid.

Roots emerged more rapidly than did shoots. For example, when cloves from bulbs stored eight weeks at $5^{\circ} \mathrm{C}$ were planted at $5^{\circ} \mathrm{C}$, roots showed 50 per cent emergence in nine days but mean sprout emergence required 33 days. This difference may have been due to the distance that sprouts had to grow, or it may have been a real time difference associated with rest. Karmarkar and Joshi (1941) found, for onions, that sprouting and rooting responded similarly to storage temperatures between $32^{\circ}$ and $90^{\circ}$ to $95^{\circ} \mathrm{F}$, and that roots appeared before sprouts.

A critical picture of rest in garlic roots and shoots should include, in addition to the data presented here, information on the time of root and leaf initiation and on rates of elongation as affected by both pre- and postplanting temperatures.

It should be pointed out that while large differences in humidity have a striking effect on dormancy of both roots and shoots, we have little information on the role of humidity in rest. Such information is particularly needed for experiments where a wide range of storage temperatures is used.

The apparent association between rapid loss of rest and high respiratory activity in garlic at certain temperatures is in accord with observations on potatoes. For potatoes, the respiration rate at $0^{\circ} \mathrm{C}$ is higher than would be expected from measurements made at other temperatures, and the rate of loss of rest is also relatively high.

No special recommendations are made here for storage of garlic to be used for commercial production. Storage temperature is known to have a marked effect on the time of maturity and the quality of garlic grown from the stored bulbs. Until the latter information is summarized, the practices known to be satisfactory for the area where the crop is grown-usually common storageshould be followed.

\section{SUMMARY}

A review of literature is presented on the influence of temperature and humidity on rest and dormancy in onion bulbs, gladiolus corms, and potato tubers. 
An investigation was made of the influence of storage of garlic bulbs at $0^{\circ}, 5^{\circ}, 10^{\circ}, 15^{\circ}$, and $20^{\circ} \mathrm{C}$ for periods up to 24 weeks on the subsequent sprouting of cloves in the field, and on sprouting and rooting of cloves in moist conditions at controlled temperatures. The influence of a range of storage temperatures on carbon dioxide production by mature, dry garlic bulbs was also studied.

For garlic planted in the field, sprout emergence was most rapid, i.e., level of rest was lowest, after preplanting storage at $5^{\circ}, 10^{\circ}$, or $15^{\circ} \mathrm{C}$, depending on the duration of the storage, while emergence was generally slowest after storage at $20^{\circ} \mathrm{C}$. When allowance was made for the field temperatures following each planting date, level of rest was found to decrease progressively with time at each preplanting storage temperature.

For cloves planted in moist sand at $5^{\circ}, 10^{\circ}, 15^{\circ}$, and $17^{\circ} \mathrm{C}$, sprout emergence was most rapid after preplanting storage at $5^{\circ} \mathrm{C}$; cloves from bulbs stored at $10^{\circ} \mathrm{C}$ sprouted almost as rapidly, and at $15^{\circ} \mathrm{C}$ only slightly more slowly. Sprout emergence was slowest after storage at $0^{\circ}$ and $20^{\circ} \mathrm{C}$. Cloves from bulbs stored at temperatures above $20^{\circ} \mathrm{C}$ were in a deeper state of rest, the higher the storage temperature. The longer that bulbs were held at each preplanting storage temperature, the more quickly the cloves sprouted, this decrease in rest being most rapid at $5^{\circ}$ and least rapid at $0^{\circ} \mathrm{C}$. Cloves receiving the same preplanting storage treatments emerged more quickly the higher the sprouting temperature, e.g., two to three times more rapidly at $15^{\circ}$ than at $5^{\circ} \mathrm{C}$.

Root emergence from cloves held in moist cloth at $5^{\circ}$ and $15^{\circ} \mathrm{C}$ was earliest after preplanting storage at $5^{\circ} \mathrm{C}$, then, in decreasing order of earliness, after $10^{\circ}, 15^{\circ}, 20^{\circ}$, and $0^{\circ} \mathrm{C}$. However, the greatest weight of roots was produced by cloves from the $10^{\circ} \mathrm{C}$ preplanting storage. The level of rest of roots, as indicated by earliness of root emergence, decreased with time at each preplanting storage temperature. For all periods of storage and all preplanting storage temperatures, cloves from similar treatments produced roots two to three times faster at $15^{\circ}$ than at $5^{\circ} \mathrm{C}$.

For bulbs which were still in a deep state of rest, the ultimate steady rates of carbon dioxide production were higher at temperatures at which rest is broken most rapidly $\left(5^{\circ}, 10^{\circ}\right.$, and $\left.15^{\circ} \mathrm{C}\right)$. Rates at $0^{\circ}$ and $20^{\circ} \mathrm{C}$ were lower. For bulbs in which rest had reached a low level before they were placed at controlled temperatures, the ultimate steady rates of carbon dioxide production were greater the higher the temperatures.

\section{ACKNOWLEDGMENTS}

Dr. P. A. Minges, now Professor of Vegetable Crops, Cornell University, helped in planning the field experiments. Dr. H. A. Jones, Head Horticulturist, United States Department of Agriculture, Beltsville, kindly read the review on rest and dormancy in the onion. Mr. Grant Baughn, Assistant Specialist in Vegetable Crops, University of California, was responsible for conducting the field test at El Centro. Miss Dora G. Hunt, Senior Laboratory Technician, University of California, gave considerable assistance at all stages of the work at Davis. We are most grateful for their kind help. 


\section{LITERATURE CITED}

Appleman, Charles O.

1914. Biochemical and physiological study of the rest period in the tubers of Solanum tuberosum. Maryland Agr. Exp. Sta. Bul. 183:181-226.

Blaauw, A. H., Annie M. Hartsema, and C. W. C. van Begkom

1941. Bloemen of bollen bij Allium Cepa. L. Koninkl. Ned. Akad. Wetenschap. Proc. Ser. C $44: 245-52$.

BOSWELL, V. R.

1924a. Influence of the time of maturity of onions upon the rest period, dormancy, and responses to various stimuli designed to break the rest period. Amer. Soc. Hort. Sci. Proc. 20 (1923) :225-33.

$1924 b$. Influence of the time of maturity of onions on the behavior during storage, and the effect of storage temperature on subsequent vegetative and reproductive development. Amer. Soc. Hort. Sci. Proc. 20 (1923) :234-39.

Claypool, L. L., and R. M. KeEFer

1942. A colorimetric method for $\mathrm{CO}_{2}$ determination in respiration studies. Amer. Soc. Hort. Sci. Proc. $40: 177-86$.

DENNY, F. E.

1930. Shortening the rest period of gladiolus by treatment with chemicals. Boyce Thompson Inst. Contrib. 2:523-34.

1936. Storage temperatures for shortening the rest period of gladiolus corms. Boyce Thompson Inst. Contrib. 8:137-40.

1938. Prolonging, then breaking, the rest period of gladiolus corms. Boyce Thompson Inst. Contrib. 9:403-8.

1939. Respiration of gladiolus corms during prolonged dormancy. Boyce Thompson Inst. Contrib. 10:453-60.

1942. Effect of a few hours of chilling upon the germination of gladiolus corms subjected to an artificially prolonged rest period. Boyce Thompson Inst. Contrib. $12: 375-86$.

EMILSSON, BörJE

1949. Studies on the rest period and dormant period in the potato tuber. Acta Agr. Suecana $3(3): 189-284$.

Fairburn, David C.

1934. Growth responses of the gladiolus as influenced by storage temperatures. Iowa Exp. Sta. Res. Bul. 170.

HARTMAN, JOHN D.

1934. Studies of the effects of storage temperature on the propagation value of potato tubers. Cornell Univ. Agr. Exp. Sta. Mem. 168.

Hartsema, Annie M.

1954. Storage of bulbs. Inst. Internat'l. du froid, annexe, Bul. 1:115-21.

Hartsema, ANNie M., and Ida Luyten

1955. Bloem- en zaadvorming bij zilveruien. Meded. Dir. Tuing. 18:49-56.

Heath, O. V. S., and M. HoLDSWORTH

1948. Morphogenic factors as exemplified by the onion plant. Soc. Expt. Biol., Symp. II. Growth. pp. 326-50. Academic Press, New York.

HeAth, O. V. S., and P. B. Mathur

1944. Studies in the physiology of the onion plant. II. Inflorescence initiation and development, and other ehanges in the internal morphology of onion sets, as influenced by temperature and day length. Ann. Appl. Biol. 31:173-86.

HOGETOP, $\mathrm{K}$.

1930. Untersuchungen über den Einfluss der Temperatur auf Keimung und Lebensdauer der Kartoffelknolle. Bot. Archiv $30: 350-413$.

HopKINS, E. F.

1924. Relation of low temperatures to respiration and carbohydrate changes in potato tubers. Bot. Gaz. 78:311-25. 
Jones, H. A.

1921. Preliminary report on onion dormancy studies. Amer. Soc. Hort. Sci. Proc. 17 (1920) :128-33.

1928. The influence of storage temperature on seed production in the Ebenezer onion. Amer. Soc. Hort. Sci. Proc. 24 (1927) :61-63.

Jones, H. A., B. A. PerRY, and W. C. Edmundson

1949. Vegetative propagation of short-day varieties of onions as an aid in a breeding program. Amer. Soc. Hort. Sci. Proc. $53: 367-70$.

KARM ARKAR, D. V., and B. M. JoSHI

1941. Investigations on the storage of onions. Indian Jour. Agr. Sci. 11:82-94.

Loomis, W. E.

1927. Temperature and other factors affecting the rest period of potato tubers. Plant Physiol. 2:287-302.

1934. Forcing gladiolus. Amer. Soc. Hort. Sci. Proc. 30 (1933) :585-88.

Loomis, W. E., and M. M. Evans

1929. Experiments in breaking the rest period of corms and bulbs. Amer. Soc. Hort. Sci. Proc. 25(1928) :73-79.

Magruder, Roy, R. E. Wester, H. A. Jones, T. E. Randall, G. B. SNyder, H. D. Brown, and LESLIE R. HAWTHORN

1941. Storage quality of the principal American varieties of onions. U. S. Dept. Agr. Cir. 618.

MaNN, Louis K.

1952. Anatomy of the garlic bulb and factors affecting bulb development. Hilgardia $21(8): 195-251$.

1954. Storage temperature and bulbing of garlic (Allium sativum L.). Huitième Congrès international du botanique, rapports et communications, sec. 11 et 12 . pp. $305-06$.

ManN, L. K., and P. A. Minges

1953. Growing garlic in California. Univ. of Calif. Veg. Crops Series No. 59. Davis, California.

MÜLLER-ThurGaU, H.

1882. Ueber Zuckeranhäufung in Pflanzentheilen in Folge wiederer Temperatur. Landw. Jahrb. 11:751-828.

MÜller-Thurgau, H., and O. SchNeIDER-ORelli

1910. Beiträge zur Kenntnis der Lebensvorgänge in ruhenden Pflanzenteilen, I. Über den Einfluss des Vorerwärmens und einiger anderer Faktoren. Flora [Jena] 101: $309-72$.

Newton, William

1927. Metabolism of nitrogen compounds in dormant and nondormant potato tubers. Jour. Agr. Res. 35:141-46.

RosA, J. T.

1928. Relation of tuber maturity and of storage factors to potato dormancy. Hilgardia $3(4): 99-124$.

RYAN, GEORGE F.

1955. Effects of temperature on rest in gladiolus corms. Amer. Soc. Hort. Sci. Proc. $65: 463-71$.

SNELL, K.

1932. Die Beschleunigung der Keimung bei der Kartoffelknolle. Berlin Deutsch. Bot. Ges. 50a:146-61.

Tedin, OloF

1938. The influence of cold-treatment upon the sprouting of the potato tuber. Bot. Notiser $1938: 257-66$.

Thompson, H. C.

1935. Effect of size of sets on yield and on the production of doubles in onions. Amer. Soc. Hort. Sci. Proc. 32(1934) :558-60.

Thompson, H. C., and Ora SMith

1938. Seedstalk and bulb development in the onion (Allium cepa L.). Cornell Univ. Agr. Exp. Sta. Bul. 708. 
ThORNTON, NoRWOOD C.

1939. Oxygen regulates the dormancy of the potato. Boyce Thompson Inst. Contrib. $10: 339-61$.

Thornton, Norwood C., and F. E. Denny

1941. Oxygen intake and carbon dioxide output of gladiolus corms after storage under conditions which prolong the rest period. Boyce Thompson Inst. Contrib. 11:42130.

Vouz, E. C., and C. G. KeYeS

1934. Gladiolus forcing: effects of exposure to high temperatures before planting. Amer. Soc. Hort. Sci. Proc. 30(1933):583-84.

Whinard, F. F., and S. W. Decker

1930. Experiments in forcing gladioli. Illinois Agr. Exp. Sta. Bul. 357.

Went, F. W.

1948. Thermoperiodicity in Vernalization and Photoperiodism. Lotsya 1:145-57.

Wright, R. C., J. I. LAURITZEN, and T. M. WhITEMAN

1935. Influence of storage temperature and humidity on keeping qualities of onions and onion sets. U. S. Dept. Agr. Tech. Bul. 475.

Wright, R. C., and Walter M. Peacock

1934. Influence of storage temperatures on the rest period and dormancy of potatoes. U. S. Dept. Agr. Tech. Bul. 424. 

The journal Hilgardia is published at irregular intervals, in volumes of about 600 pages. The number of issues per volume varies.

Subscriptions are not sold. The periodical is sent as published only to libraries, or to institutions in foreign countries having publications to offer in exchange.

You may obtain a single copy of any issue free, as long as the supply lasts; please request by volume and issue number from:
Agricultural Publications
Room 22 Giannini Hall
University of California
Berkeley 4, California

The limit to nonresidents of California is 10 separate issues on a single order. A list of the issues still available will be sent on request.

In our publications it is sometimes convenient to use trade names of products or equipment rather than scientific identifications. In so doing it is unavoidable in some cases that similar products which are on the market under other trade names may not be cited. No endorsement of named products is intended nor is criticism implied of similar products which are not mentioned. 